Abstract

\title{
Giving once, giving twice: A two-period field experiment on inter- temporal crowding in charitable giving
}

We study intertemporal crowding between two fundraising campaigns for the same charitable organization by manipulating donors' beliefs about the likelihood of future campaigns in two subsequent field experiments. The data shows that initial giving is decreasing in the likelihood of a future campaign while subsequent giving increases in initial giving. While this refutes the predictions of a simple expected utility model, the pattern is in line with a model that allows for (anticipated or unanticipated) habit formation provided that donations in the two periods are substitutes.

JEL classifications: C93, D64, D12

Keywords: charitable giving, field experiments, intertemporal crowding

\footnotetext{
* We thank all those at the Dresden Opera House and actori for making this project possible. We thank Arnim Falk, Judd B. Kessler, David Reiley, Ted Bergstrom, Yan Chen, Lata Gangadharan, Philip Grossman, Andreas Lange, Ragan Petrie, Michael Sanders, Sarah Smith, and participants of the BBE Workshop and the workshop on Recent Advances in the Economics of Philanthropy for helpful suggestions and comments. We are grateful to Jana Wittig, Rita Reischl, and Katharina Dorn for excellent research assistance, and many others for help in conducting the field experiment. Steffen Huck gratefully acknowledges financial support by Deutsche Forschungsgemeinschaft (DFG) through collaborative research center CRC TRR 190. This paper has been screened to ensure that no confidential information is revealed.
} 


\section{Introduction}

There are numerous ways to encourage charitable giving, ranging from simple solicitations to complex incentive schemes. For all these methods the fundamental question arises as to whether they crowd in or crowd out contributions. This has been most extensively studied for tax rebates (see, for example, the survey by Peloza and Steel 2005 or Adena 2014) and matching incentives (see, for example, Huck and Rasul 2011 and the references cited therein). The evidence, especially from field experiments, points to the prevalence of crowding out. In the presence of matching, donors reduce their out-of-pocket donations while the overall amount reaching the charity increases. More recently, the question of whether solicitations for a new cause generate additional donations or simply replace donations that would have been made to other causes has attracted considerable attention (see Meer 2017 and Scharf, Smith, and Ottoni-Wilhelm 2017, which suggest that fundraising does generate additional donations). In this paper, we examine a similarly fundamental question: whether there is crowding between repeated fundraising calls for one and the same charitable cause. This is important as almost all charities that solicit donations engage in repeated fundraising calls.

In order to study intertemporal crowding, we conduct a repeated large-scale experiment in conjunction with a German opera house. Our identification strategy relies on manipulating donors' beliefs about the likelihood of future fundraising calls. In the first year, opera customers receive a fundraising letter asking them, for the first time in the history of the opera house, to contribute to a charitable project. The project offers workshops for children from economically disadvantaged areas with a focus on culture and integration. In our baseline treatment, customers receive a standard fundraising letter. In our treatment group, we push up donors' beliefs about the likelihood of future fundraising calls through the insertion of additional words and phrases that are suggestive of repetition in the future. We repeat these manipulations in year 2 with a subset of previous and a set of new recipients.

A simple expected utility framework makes twin predictions for how first-period donations depend on beliefs about the future and how second-period donations depend on first-period choices. Specifically, if donations in the two periods are substitutes, the expected utility framework predicts that first-period donations decrease in the probability of a further period (crowding out) and that second-period donations decrease in first-period donations if there is a 
second period. In contrast, if repeated donations are complements, first-period donations will increase in the probability of a further period (crowding in) and second-period donations will increase in first-period donations.

Our data set shows that donors give less when their beliefs about a second period of fundraising are shifted upwards (that is, there is crowding out) but also that they give more in the second period when they have given more in the first period (that is, there is persistence in giving). Taking these two findings together, our results refute the simple expected utility framework. However, we are able to show that a simple adaptation of the expected utility model that accounts for the possibility of habit formation (be it anticipated or unanticipated) can bring it in line with the data if donations in the two periods are substitutes.

Our identification relies on the demonstration of two facts. First, we show that there is no evidence for differential selection into becoming a donor depending on the year-1 treatment. This is important, since our model makes predictions conditional on giving. Second, we show that in the second fundraising call, where we continue our belief manipulation, the actual fact of repeating the solicitation aligns beliefs about the future. We establish this by showing that those individuals who receive a call for the second time but give for the first time do not exhibit a response to the treatments.

There is a small number of studies that have previously addressed repeated giving to the same institution and persistence in giving is a feature of philanthropic behavior that has been observed before. For example, in a field experiment, Landry et al. (2010) document that previous donors are more likely to give and contribute more than other donor types. Frey and Meier (2004) study repeated giving by students and find that the majority of students contribute each year, that is, giving in one year is a strong predictor for giving in the next year. Long-lasting effects of treatment manipulations on giving in subsequent fundraising drives are documented by Adena, Huck, and Rasul (2014) and Kamdar et al. (2015). Adena, Huck, and Rasul (2014) demonstrate that suggestions in one fundraising call still influence giving levels in a subsequent call. Kamdar et al. (2015) show that a treatment that encourages giving by promising to never bother donors again has long-lasting positive effects on donors who respond to the treatment by giving more but then do not make use of the prominently featured opt-out possibility. 
In contrast to such findings of persistence on the intensive margin, Huck and Rasul (2010) show that non-responses in a campaign do not necessarily imply that recipients of a call do not value the charitable good. Rather the non-response might simply be due to time-varying transaction costs, which is why reminders can be effective. Damgaard and Gravert (2018) add a caveat to this by showing that reminders can lead to increased unsubscriptions from mailing lists.

Finally, there is some work that speaks to the question of substitutability between donations to different causes promoted by the same charity. Cairns and Slonim (2011) show that when churchgoers learn that a second collection (for a second cause) will take place during the same Sunday Mass they reduce their donations to the first collection, but the second collection increases overall donations. This suggests that the two causes are perceived as imperfect substitutes. Relatedly, Adena and Huck (2017) study fundraising calls by one organization for two different causes where the money for the second cause is generated through funds that match donations for the first cause. They show that such matching schemes can reduce crowding out provided that the second cause is perceived as a complement to the first.

Relative to these existing results, we show that (i) models of repeated giving to the same cause require an element of habit formation; and (ii) that donations to the same cause in different time periods are substitutes. Notice that the second finding does not necessarily follow from the papers cited above, which suggest substitutability between similar causes, as sustaining the viability of a cause over time could induce intertemporal complementarities. Our contribution has some fundamental implications for the understanding of philanthropic behavior as well as immediate practical consequences for fundraisers, who, when starting a new project, should not necessarily emphasize that future calls will occur, even if they are planned. In our case donors in the baseline treatment give around $60 \%$ more than those whose beliefs about the likelihood of a second call are shifted upwards, and these baseline donors continue to give more in the future.

We proceed as follows. In Section 2 we first present a simple reduced-form model sketch showing how intertemporal crowding is a function of beliefs about future campaigns and the substitutability between repeated donations. We then enrich the model by introducing an element of habit formation and demonstrate how this alters predictions. Section 3 presents the design and results of our year-1 experiment and Section 4 those of the year-2 experiment. Section 5 concludes. 


\section{A two-period model sketch and a behavioral alternative}

Consider a potential donor who, over two periods, has to allocate her income between private consumption and a charitable good. In period 1 the donor faces certainty that she can make a donation (because she actually is confronted with a fundraising call). For period 2 the donor faces uncertainty and we denote her beliefs about the likelihood of a future fundraising call by $p$. The donor's problem can be reduced to an expected utility maximization problem where her utility function simply depends on the amounts donated in the two periods, $V\left(x_{1}, x_{2}\right)$. We assume that $V$ is increasing in both arguments and strictly concave. The cross derivative is positive if $x_{1}$ and $x_{2}$ are complements and negative if they are substitutes.

If there is a second-period fundraising call, the donor maximizes $V\left(\hat{x}_{1}, x_{2}\right)$ with $\hat{x}_{1}$ denoting her actual contribution in period 1 . Let $\tilde{x}_{2}\left(\hat{x}_{1}\right)$ be the solution to that problem and notice that $\tilde{x}_{2}$ is increasing in $\hat{x}_{1}$ for complements and decreasing for substitutes.

Anticipating optimal behavior in period 2 the donor's first-period problem can then be written as

$$
\max p V\left(x_{1}, \tilde{x}_{2}\left(x_{1}\right)\right)+(1-p) V\left(x_{1}, 0\right)
$$

where the second term represents the situation that no further fundraising call happens, that is, the donor has to consider that she might be "stuck" with $x_{2}=0$ if the fundraising ceases.

The first-order condition is

$$
p\left(\frac{\partial V\left(x_{1}, \tilde{x}_{2}\left(x_{1}\right)\right)}{\partial x_{1}}+\frac{\partial V\left(x_{1}, \tilde{x}_{2}\left(x_{1}\right)\right)}{\partial x_{2}} \frac{\partial \tilde{x}_{2}\left(x_{1}\right)}{\partial x_{1}}\right)+(1-p) \frac{\partial V\left(x_{1}, 0\right)}{\partial x_{1}}=0
$$

which, as $x_{2}$ is chosen optimally, simplifies to

$$
p\left(\frac{\partial V\left(x_{1}, \tilde{x}_{2}\left(x_{1}\right)\right)}{\partial x_{1}}\right)+(1-p) \frac{\partial V\left(x_{1}, 0\right)}{\partial x_{1}}=0
$$

Applying the implicit function theorem we can show how the period-1 donation depends on the donor's beliefs about the likelihood of the continuation of the project. Specifically, we get 


$$
\frac{\partial x_{1}}{\partial p}=-\frac{\frac{\partial V\left(x_{1}, \tilde{x}_{2}\left(x_{1}\right)\right)}{\partial x_{1}}-\frac{\partial V\left(x_{1}, 0\right)}{\partial x_{1}}}{p\left(\frac{\partial^{2} V\left(x_{1}, \tilde{x}_{2}\left(x_{1}\right)\right)}{\partial x_{1}^{2}}+\frac{\partial^{2} V\left(x_{1}, \tilde{x}_{2}\left(x_{1}\right)\right)}{\partial x_{1} \partial x_{2}} \frac{\partial x_{2}}{\partial x_{1}}\right)+(1-p) \frac{\partial^{2} V\left(x_{1}, 0\right)}{\partial x_{1}^{2}}}
$$

which for concave $\mathrm{V}$ is positive if the numerator is positive. ${ }^{1}$ This shows that the effect of the donor's beliefs on her donation depends on whether $x_{1}$ and $x_{2}$ are substitutes or complements. For substitutes the numerator is negative, hence, the prediction that a greater $p$ crowds out donations. For complements a greater $p$ will crowd in donations.

If the second period is the final period and fundraising does take place, the prediction of the sketched model comes simply from $\tilde{x}_{2}\left(\hat{x}_{1}\right)$ which is increasing for complements and decreasing for substitutes.

In our experiment, recipients may, of course, consider more periods than two in which case their behavior in the second round of fundraising will still be a function of their beliefs about the future. As the data will show that all beliefs have converged in the second period, we can refrain from modelling this in more detail. The period-2 prediction simply remains that period-2 donations will be increasing (decreasing) in period-1 donations for complements (substitutes).

Hence, for the simple orthodox expected utility framework we predict that either $\frac{\partial x_{1}}{\partial p}<0$ and $\frac{\partial x_{2}}{\partial x_{1}}<0$ (for substitutes) or $\frac{\partial x_{1}}{\partial p}>0$ and $\frac{\partial x_{2}}{\partial x_{1}}>0$ (for complements).

The next two sections with the results from our two experiments will establish that this prediction is refuted by the data. Our data set shows that $\frac{\partial x_{1}}{\partial p}<0$ and $\frac{\partial x_{2}}{\partial x_{1}}>0$. Specifically, we observe that period-2 donations are either equal or very close to period-1 donations which suggests some form of habit formation.

This raises the question whether a simple model that accounts for habit formation can be brought into line with the data. If donors simply repeat their first-period choice in the second period, we have to ask whether they anticipate the establishment of a habit in the first period or not. If they do not, we would conclude that, from the viewpoint of period 1, the donations are substitutes but,

\footnotetext{
${ }^{1}$ Notice that the first product in the denominator has the opposite sign of the second principle minor of the Hessian of $\mathrm{V}$, which, for concave $\mathrm{V}$, renders the whole denominator negative.
} 
when the second period arrives, donors switch their mode of behavior. They optimize in period 1 believing that they will optimize in period 2 but then simply repeat their initial choice in period 2 without re-optimizing $V$. This would be in line with our data.

A more subtle alternative would model donors as anticipating their habit formation. Here, we consider the simple case where donors assume in the first period that they will repeat their firstperiod choice in the second period, that is $x_{2}\left(x_{1}\right)=x_{1}$. Such sophisticated habit forming donors would then, in the first period, solve the following problem

$$
\max p V\left(x_{1}, x_{1}\right)+(1-p) V\left(x_{1}, 0\right) .
$$

In Appendix A we show that the solution to this problem implies $\frac{\partial x_{1}}{\partial p} \leq 0$ for substitutability between period-1 and period-2 donations. Hence, on the basis of our simple model sketches and the data that we document below, we will be able to conclude that (i) donations in the two periods are substitutes and (ii) that donors do not behave like in an orthodox expected utility framework but rather exhibit some form of habit formation. Whether they anticipate that they will repeat their first period choice when a second period arrives or not we are, however, unable to tell.

\section{The year-1 experiment}

\subsection{Design}

We conducted our experiment with the Semper Opera in Dresden, an institution that had previously not engaged in this type of fundraising activities. This was important for our design as it left open the possibility that the fundraising call may not be repeated. In other words, it allows us to have a true first period in which beliefs are not yet formed. At the end of November 2015 the opera house sent 35,705 letters to its customers asking them to support a social youth project that enhances cultural education and social integration (see Appendix $C$ for details of the mailout).

Recipients were randomly selected from the opera's database of individuals who had attended at least one opera performance in the opera season 2014/2015 and lived in Germany, Austria or 
Switzerland. ${ }^{2}$ Recipients were randomly assigned to one of three treatment groups, such that there were almost 12,000 subjects per treatment. ${ }^{3}$ Given that a number of customer characteristics were available from the database, we made sure that the treatment groups were sufficiently balanced. In Appendix B, Table B1 we present evidence that treatment groups do not differ significantly in terms of observables: the sum of money spent on opera tickets, the number of purchased tickets, the average price per ticket, the distance from the opera house, and dummy variables for season ticket holder, females, couples, academic degree, ${ }^{4} \mathrm{PhD}$, professor title, living locally in Dresden, living in Germany, living in a big city, and being an online customer.

In the control treatment (A) the recipients received a solicitation letter that asked them in a standard way to donate money. The second treatment (B) and third treatment (C) stressed intertemporal aspects of the fundraising and the project. Specifically, the letters differed from the control at seven places in the text where in treatment $B$ and $C$ the following phrases were injected: permanently, over the long-term, year by year, in the year 2015 (twice), this year, première: first (see the letter and attached flyer in the Appendix C). This was done to create a higher salience of the possible repetition of the fundraising and to increase the expectation that the present letter will be the first in an annual series. To put it differently, in treatments B and C we shifted the beliefs about the probability of repetition, $p$, upwards. Treatment $\mathrm{C}$ was identical to $\mathrm{B}$ but added an option to set $p=0$ : there was a footnote informing about the possibility of unsubscribing from future fundraising mailings. While we introduced this treatment to have a measure of ask avoidance, it can be also considered as a very weak version of the "once and done” treatment in Kamdar et al. (2015), which promised no further fundraising letters upon donating.

\footnotetext{
${ }^{2}$ Corporates, employees of the opera house and other selected customers were excluded.

${ }^{3}$ We allocated exactly 11,905 individuals to each of the treatments. However, between treatment assignment and mailing ten subjects passed away or got otherwise erased from the database and were not replaced.

${ }^{4}$ Academic degrees can only be taken into account if stated (truthfully or not). However, a standard (online) form in Germany contains an open space for title. This is often used (especially by the older generations) to enter any title including academic degrees.
} 
All letters contained information that seed money of $€ 15,000$ had been provided by an anonymous donor. ${ }^{5}$ Beyond that, one additional page described the project in more detail, and this was equal in all treatments (see again Appendix C for details).

\subsection{Results}

Overall, 455 individuals donated, resulting in a response rate of $1.27 \%$. The average donation was €53.60, yielding a return of 68 cents per mail-out, and a total income of $€ 24,388$ (excluding seed money that covered the costs of mailing). Table 1 summarizes raw results by treatment. Table 2 presents OLS regressions with the response rate, positive donation, and return as dependent variables and controls. Wald tests of equality of coefficients in the lower panel of Table 2 provide tests of differences between treatments. ${ }^{6}$ In all regressions we exclude the constant and demean the control variables such that the coefficients on treatment dummies correspond to the averages in Table 1 but are corrected for any potential differences in available characteristics. Given that the samples were balanced on available characteristics, raw and corrected averages do not differ with respect to the response rate and return. Note that, as our model makes predictions relating to the intensive margin, we will pay particular attention to the average donation conditional on giving and later study behavior of year-1 donors in the year-2 campaign. The validity of such an approach relies heavily on ruling out potential selection into becoming a donor that relates to our treatment manipulation. In other words, we want to believe that the actual donors in treatment $\mathrm{A}$ would have become donors if receiving treatment $\mathrm{B}$ or $\mathrm{C}$ as well (and vice versa). Empirically, we make the following observations: (i) The response rate is not affected by treatments, that is, the share of recipients who decide to give is very similar between treatments. This can be inferred from Table 2, column I: the coefficients are similar and p-values for Wald tests of equality of coefficients are high. (ii) In a regression of donation values on treatment dummies, the inclusion of observable controls has negligible effects on coefficient sizes (that correspond to averages here), that is, there is no meaningful selection on observables. This can be inferred when comparing Table 1, Column 4 to Table 2, Column 2. (iii) The observables matter for the donation value chosen $(F(12,35575)=18.15$ and Prob $>F=0.0000$ in

\footnotetext{
${ }^{5}$ This was done to enhance giving as previous research strongly indicates that lead donations serve as a quality signal (see, for example, Huck and Rasul, 2011 for field evidence on signaling). The anonymous lead gift was provided by us.

${ }^{6}$ In Table B2 in the Appendix we provide additional tests based on Table 1. Figure B1 in the Appendix shows the distribution of different donation amounts between treatments.
} 
a base specification with controls, Table 2, Column 2) but they do not do so differentially dependent on treatment (individual characteristics that are interacted with treatment dummies jointly play no role, $\mathrm{F}(24,35551)=1.22$ and Prob $>\mathrm{F}=0.2122$ while individual characteristics still matter, $\mathrm{F}(12,35551)=8.16$ and Prob $>\mathrm{F}=0.0000$ in a specification with interactions, not presented here). (iv) A direct comparison of averages of individual characteristics by treatment yields no differences between treatments when accounting for multiplicity testing (List, Shaikh, and $\mathrm{Xu}, 2016$; without multiplicity corrections 3 out of 16 tests are significant at 10\%). This can be inferred from Table 3. (v) In order to measure potential selection based on unobservables, we follow Oster (2019) who extends the approach by Altonji, Elder, and Taber (2005). The calculation is based on a regression corresponding to Table 2, Column 2 but with only an A treatment dummy (and a constant). The treatment effect of A relative to B and C is equal to 26.90 without controls and to 24.91 including available controls (not presented). Assuming $\delta=1$, that is, an effect of unobservables being equal to observables, and $R_{\max }=1.3 \tilde{R}$, the bias-corrected coefficient is reduced only slightly and equal to $24.12{ }^{7}$ From a different perspective, the effect of unobservables would have to be more than 15.5 times as large as that of observables in order to wipe out the treatment effect.

All of the above means that potential selection effects are at most small, which makes us confident that the set of actual donors in all treatments is near identical. Thus, we can proceed with testing our model predictions and drawing conclusions about the behavior of donors.

Treatment A generated much higher donations than the remaining treatments. The average positive donation in treatment A was $€ 71.46$ compared to only $€ 45.91$ in treatment $B$ and $€ 42.24$ in treatment $\mathrm{C}$ (Table 1, Column 4). These averages are similar when corrected for potentially different composition of the samples (€70.85, €50, and €41.35 respectively in Table 2, Column 2). The differences between treatment $A$ and the remaining treatments are significant at the 1 and $5 \%$ level according to Wald tests (see bottom panel of Table 2, Column 2). ${ }^{8}$ Figure 1 shows the

\footnotetext{
${ }^{7} \tilde{R}$ is R squared that we obtain from the OLS regression with controls, $R_{\max }$ is the $\mathrm{R}$ squared that we would at most expect in a specification which includes the unobservables. Oster (2019) uses $R_{\max }=1.3 \tilde{R}$ with the justification that many observational studies do not survive this threshold. However, she suggests studying sensitivity with respect to the choice of $R_{\max }$. In our case the effect of treatment $\mathrm{A}$ is only wiped out with $R_{\max }>8 \tilde{R}$, a very large increase given that predicting charitable giving turns extremely difficult.

${ }^{8}$ In Table A2 in the Appendix, we provide other set of comparisons between treatments based on raw data in Table 1. According to a t-test, the differences between A and the remaining treatments are significant at the $5 \%$ level. The
} 


\section{cumulative distribution of positive donations (log of donations for expositional reasons) in}

different treatments. There is a visible shift of distributions from A to B and C that corresponds to first-order stochastic dominance. ${ }^{9}$

Table 1: Summary statistics for donations in year 1

\begin{tabular}{|c|c|c|c|c|c|c|c|c|c|c|c|}
\hline " Treatment & " Description & $\begin{array}{c}\text { Number of } \\
\text { recipients } \\
\text { (1) }\end{array}$ & $\begin{array}{c}\begin{array}{c}\text { Number of } \\
\text { donations }\end{array} \\
\text { (2) }\end{array}$ & $\begin{array}{c}\begin{array}{c}\text { Response } \\
\text { rate }\end{array} \\
\text { (3) }\end{array}$ & $\begin{array}{c}\text { Average } \\
\text { positive } \\
\text { donation } \\
\text { (4) }\end{array}$ & $\begin{array}{c}\text { Median } \\
\text { (5) }\end{array}$ & $\begin{array}{c}\text { Minimum } \\
\text { (6) }\end{array}$ & $\begin{array}{c}\text { Maximum } \\
\text { (7) }\end{array}$ & $\begin{array}{c}\text { Return } \\
\text { (8) }\end{array}$ & $\begin{array}{c}\text { Number of } \\
\text { unsubscriptions } \\
\text { (9) }\end{array}$ & $\begin{array}{c}\begin{array}{c}\text { Unsubscription } \\
\text { rate }\end{array} \\
\text { (10) }\end{array}$ \\
\hline A & Control & 11,903 & 158 & $\begin{array}{c}0.013 \\
(0.001)\end{array}$ & $\begin{array}{c}71.456 \\
(10.467)\end{array}$ & 37.5 & 5 & 1000 & $\begin{array}{c}0.949 \\
(0.157)\end{array}$ & 10 [6] & $\begin{array}{l}0.0008 \\
(0.000)\end{array}$ \\
\hline B & $\begin{array}{c}\text { Higher } \\
\text { beliefs } \\
\text { about the } \\
\text { probability } \\
\text { of future } \\
\text { mailing }\end{array}$ & 11,902 & 150 & $\begin{array}{c}0.013 \\
(0.001)\end{array}$ & $\begin{array}{l}45.907 \\
(3.779)\end{array}$ & 25 & 1 & 300 & $\begin{array}{c}0.579 \\
(0.067)\end{array}$ & $7[3]$ & $\begin{array}{l}0.0006 \\
(0.000)\end{array}$ \\
\hline $\mathrm{C}$ & $\begin{array}{l}\text { Higher } \\
\text { beliefs } \\
\text { about the } \\
\text { probability } \\
\text { of future } \\
\text { mailing + } \\
\text { opt out }\end{array}$ & 11,900 & 147 & $\begin{array}{c}0.012 \\
(0.001)\end{array}$ & $\begin{array}{l}42.239 \\
(4.936)\end{array}$ & 20 & 3 & 500 & $\begin{array}{c}0.522 \\
(0.074)\end{array}$ & $44[40]$ & $\begin{array}{l}0.0037 \\
(0.001)\end{array}$ \\
\hline
\end{tabular}

Notes: Columns 3, 4, 8, and 10: mean, standard error in parentheses. Column 9: Total number of individuals that asked for erasing from the database (may include reasons such as death or no interest in the opera anymore). Square brackets indicate unsubscription from the fundraising only; Columns 4-8: monetary amounts are measured in Euros.

Table 2: Regression results in year 1

\begin{tabular}{|c|c|c|c|}
\hline & Response rate & Average positive donation & Return \\
\hline & $(1)$ & $(1)$ & (3) \\
\hline \multirow[t]{2}{*}{ A } & 0.013 & 70.846 & 0.949 \\
\hline & $(0.001)$ & (7.339) & $(0.108)$ \\
\hline \multirow[t]{2}{*}{ B } & 0.013 & 50.003 & 0.580 \\
\hline & $(0.001)$ & $(7.592)$ & $(0.108)$ \\
\hline \multirow[t]{2}{*}{$\mathrm{C}$} & 0.012 & 41.347 & 0.520 \\
\hline & $(0.001)$ & $(7.589)$ & $(0.108)$ \\
\hline Controls & yes & yes & yes \\
\hline Observations & 35705 & 455 & 35705 \\
\hline$R^{2}$ & 0.019 & 0.326 & 0.006 \\
\hline Comparison groups & \multicolumn{3}{|c|}{ Wald tests of equality of coefficients p-values } \\
\hline $\mathrm{A}=\mathrm{B}$ & 0.6590 & 0.0357 & 0.0154 \\
\hline $\mathrm{B}=\mathrm{C}$ & 0.8470 & 0.3873 & 0.6920 \\
\hline$A=C$ & 0.5259 & 0.0030 & 0.0048 \\
\hline
\end{tabular}

Notes: OLS regressions, no constant, controls demeaned, standard errors in parentheses. Controls include: Number of tickets in the past season (logarithm), average price of tickets in the past season, Distance in $\mathrm{km}$ and the following dummies: internet customer, female, couple, titled, living in Dresden.

Mann-Whitney U (MWU) test rejects the equality of distributions between $\mathrm{A}$ and $\mathrm{C}$ at $1 \%, \mathrm{~B}$ and $\mathrm{C}$ at $10 \%$, but not between $\mathrm{A}$ and $\mathrm{B}(\mathrm{p}=0.168)$. A nonparametric equality-of-medians test rejects the equality between treatment $\mathrm{A}$ and treatment $\mathrm{C}$ at $10 \%$.

${ }^{9}$ Though, Kolmogorov-Smirnov test does reject the equality of distributions only between A and C at $10 \%$. 
The effect on the overall return rendered treatment A much more effective, with a return of 95 cents per mail-out. Treatment B generated 58 cents and treatment C yielded only 52 cents. The differences between treatment $\mathrm{A}$ and the remaining treatments are significant at the $5 \%$ level (Wald test, see bottom panel of Table 2, Column 3).

Figure 1: Cumulative distribution of log of positive donations in different treatments

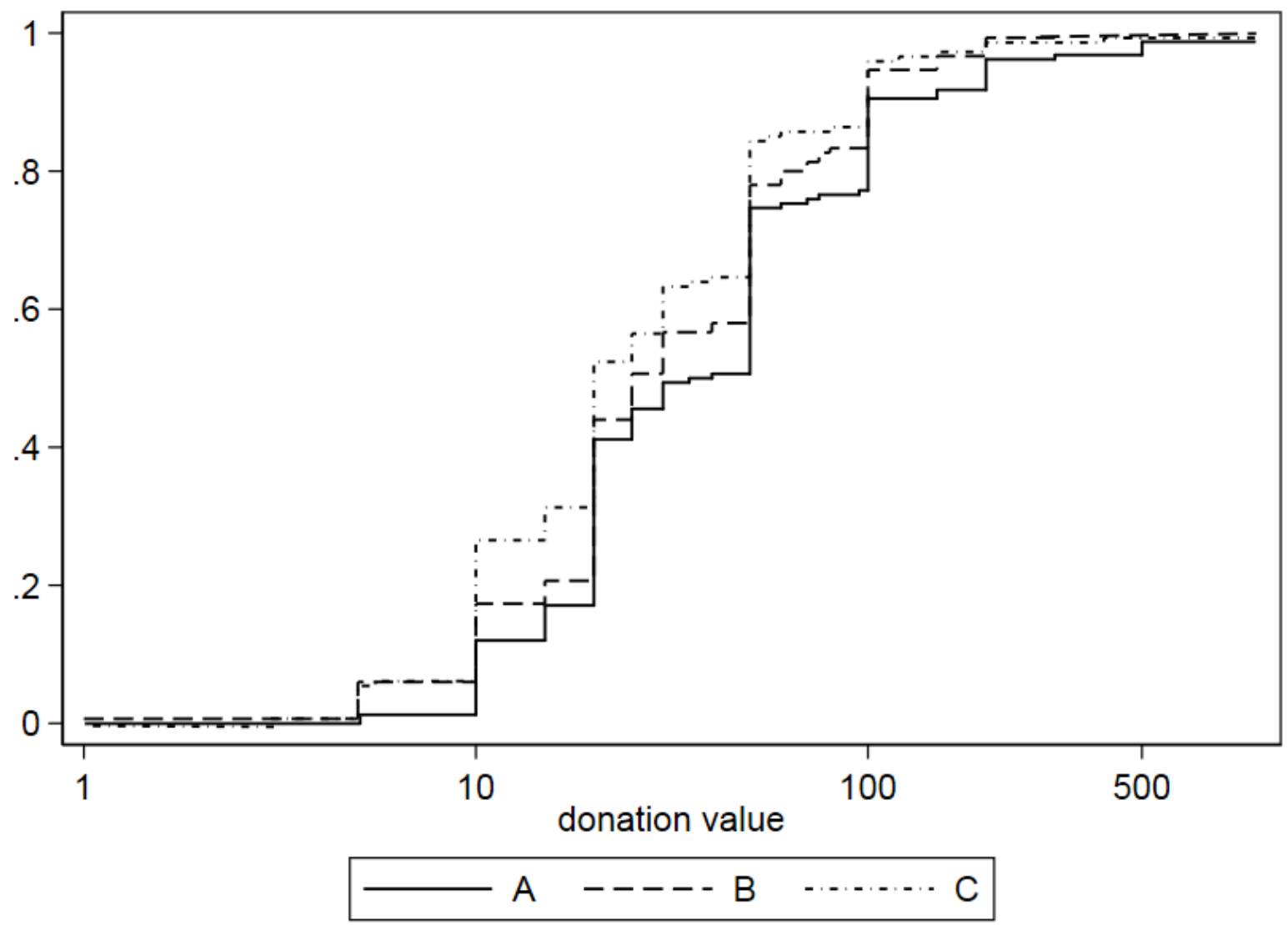

Notes: Horizontal axis: donations presented at a log scale; Treatment A: Control; Treatment B: Higher beliefs about the probability of future mailing; Treatment C: Higher beliefs about the probability of future mailing + opt out option.

The overall unsubscription rate was as low as $0.06-0.08 \%$ in treatments A and B. In treatment C, which highlighted the option to unsubscribe explicitly in a footnote, the rate was $0.37 \%$. The difference between treatment $\mathrm{C}$ and the remaining treatments is significant with $p<0.0001$. Notice that only one person in treatment $\mathrm{C}$ donated (€20) and unsubscribed from the mailing list. In light of the recent literature on ask avoidance (Andreoni, Rao, and Trachtman, 2017 and DellaVigna, List, and Malmendier, 2012), the unsubscription rates are extremely low, which 
suggests that our recipients do not mind receiving mail from the opera house. ${ }^{10}$ This is important for the interpretation of the differences between the main treatments A and B: we can exclude ask avoidance as an alternative explanation for differences in observed behavior in A and B.

Note that our treatments B and C are informationally equivalent to Kamdar et al. (2015) but they differ in the way they were framed. While Kamdar et al. (2015) stressed very prominently the one-off character of the mailing ("once and done”), we included the opt-out option only in the footnote. In fact, the framing in Kamdar et al. (2015) suggested that only donors can opt out of future mailing. We did not use such a frame as unsubscription from a mailing list is in Germany, by law, always an option. Altogether our treatments B and C can be considered as a much milder version of Kamdar et al. (2015). So, perhaps it is not surprising that our treatment comparison does not replicate their effect. ${ }^{11}$ As giving behavior remained untouched by the treatment variations, we pooled participants from B and C in year 2 as will be described in more detail below.

Overall, we find strong evidence that increasing the likelihood of continuing the project and fundraising for it massively decreases donations (In line with model predictions, we draw our conclusions from the intensive margin. Note, however, that the consideration of the combined effect leads to identical conclusions). In other words, from the vantage point of our simple expected utility model, the year-1 data suggests that repeated donations to the same cause are substitutes. However, as we will see in the next section, the simple model is not in line with our data from year 2. Rather, we will conclude that donors exhibit some elementary form of habit formation.

\footnotetext{
${ }^{10}$ This assumes that letter recipients read the letters and the footnote. It is plausible that a fraction of recipients did not even open the letter but this should be equal across treatments. Note that the individual costs of unsubscription are low, which, combined with low unsubscription rate, suggests that most recipients still prefer receiving the letter.

${ }^{11}$ Notice that one could view our treatments A and B as an even milder version of Kamdar et al. (2015), where "once and done" suggests $p=0$ versus $p>0$ in their control, while in our case $0<p_{A}<p_{B}$. Here, the results are more similar with lower $p$ rendering higher revenue. However, the treatments are effective on different margins: the extensive margin in Kamdar et al. (2015) and the intensive margin in our case.
} 
Table 3: Donors characteristics in different treatments

\begin{tabular}{|c|c|c|c|c|c|c|c|c|c|c|}
\hline $\begin{array}{l}\text { Treat } \\
\text { ment }\end{array}$ & Description & $\begin{array}{l}\mathrm{N} \\
(1)\end{array}$ & $\begin{array}{c}\text { Total spent } \\
\text { on tickets } \\
\text { (2) }\end{array}$ & $\begin{array}{l}\text { No. of } \\
\text { tickets } \\
(3)\end{array}$ & $\begin{array}{l}\text { Average } \\
\text { price } \\
(4)\end{array}$ & $\begin{array}{c}\text { Internet } \\
\text { customer } \\
\text { (5) }\end{array}$ & $\begin{array}{c}\text { female } \\
\text { (6) }\end{array}$ & $\begin{array}{l}\text { titled } \\
\text { (7) }\end{array}$ & $\begin{array}{c}\text { Dresden } \\
\text { (8) }\end{array}$ & $\begin{array}{c}\text { Distance in } \\
\text { km } \\
(9)\end{array}$ \\
\hline A & Control & 158 & $\begin{array}{r}324.139 \\
(29.486)\end{array}$ & $\begin{array}{r}6.797 \\
(0.611)\end{array}$ & $\begin{array}{c}57.557 \\
(2.666)\end{array}$ & $\begin{array}{r}0.304 \\
(0.037)\end{array}$ & $\begin{array}{r}0.468 \\
(0.040)\end{array}$ & $\begin{array}{r}0.133 \\
(0.027)\end{array}$ & $\begin{array}{r}0.430 \\
(0.040)\end{array}$ & $\begin{array}{r}140.506 \\
(14.297)\end{array}$ \\
\hline B & $\begin{array}{l}\text { Higher beliefs } \\
\text { about the } \\
\text { probability of } \\
\text { future mailing }\end{array}$ & 150 & $\begin{array}{r}282.507 \\
(25.023)\end{array}$ & $\begin{array}{r}6.180 \\
(0.686)\end{array}$ & $\begin{array}{r}58.774 \\
(2.794)\end{array}$ & $\begin{array}{r}0.213 \\
(0.034)\end{array}$ & $\begin{array}{r}0.540 \\
(0.041)\end{array}$ & $\begin{array}{r}0.067 \\
(0.020)\end{array}$ & $\begin{array}{r}0.367 \\
(0.040)\end{array}$ & $\begin{array}{r}148.372 \\
(14.423)\end{array}$ \\
\hline $\mathrm{C}$ & $\begin{array}{l}\text { Higher beliefs } \\
\text { about the } \\
\text { probability of } \\
\text { future mailing } \\
\text { + opt out }\end{array}$ & 147 & $\begin{array}{c}309.347 \\
(24.966)\end{array}$ & $\begin{array}{r}6.510 \\
(0.583)\end{array}$ & $\begin{array}{r}61.624 \\
(3.064)\end{array}$ & $\begin{array}{r}0.272 \\
(0.037)\end{array}$ & $\begin{array}{r}0.476 \\
(0.041)\end{array}$ & $\begin{array}{r}0.075 \\
(0.022)\end{array}$ & $\begin{array}{r}0.401 \\
(0.041)\end{array}$ & $\begin{array}{r}152.108 \\
(15.130)\end{array}$ \\
\hline$A=B$ & & T-test p-value & 0.285 & 0.501 & 0.753 & 0.071 & 0.210 & 0.054 & 0.255 & 0.699 \\
\hline$A=C$ & & T-test p-value & 0.704 & 0.735 & 0.316 & 0.543 & 0.891 & 0.099 & 0.609 & 0.577 \\
\hline
\end{tabular}

Notes: Upper panel, Columns 2-9: mean, standard error in parentheses; Upper panel, Columns 2 and 4: monetary amounts in Euros; Treatment A: Control; Treatment B: Higher beliefs about the probability of future mailing; Treatment C: Higher beliefs about the probability of future mailing + opt out option.

\section{The year 2 experiment}

\subsection{Design}

The fundraising campaign was repeated a year later on a smaller scale. All previous donors (referred to as year-1 donors) and 25\% of year-1 non-donors (referred to as year-1 non-donors) were included in the new fundraising campaign provided they did not unsubscribe. The 25\% of year-1 non-donors were selected based on their observable individual characteristics that made them most promising to become future donors (see Appendix B for a more detailed explanation of the selection procedure). Over 3,000 individuals from the past treatment A were again allocated to treatment A (now denoted A-A), that is, they again received a standard letter. Selected individuals from the previous treatments B and C received now, equally likely, letters in the style of the previous treatments A and B. We pooled year- 1 treatments B and $\mathrm{C}^{12}$ and denote the new treatments as BC-A and BC-B. ${ }^{13}$ In total, 6,149 individuals received a neutral donation ask (treatment A-A and BC-A) and 3,072 received a letter with extra words (revival: second, permanently, over the long term, year by year, in the year 2016, this year, in the year 2016) that

\footnotetext{
12 This was based on the observation that recipients in B and C did not differ much in their donative choices (see Table 2).

${ }^{13}$ We did not include A-B treatment since we were restricted to only a small sample, and did not want to lose power.
} 
suggested the regular character of the project and fundraising activities (treatment BC-B). All letters additionally informed recipients about seed money of $€ 10,000^{14}$ (see Appendix $C$ for details of the letter and attached flyer).

Additionally, we selected a smaller sample of customers with the highest predicted donation who were not included in the fundraising campaign in year 1 (we call these the new recipients). Treatments A and B were assigned to around 2,000 customers each (now denoted as 0-A and 0B).

With our year-2 experiment, we can answer the following three questions. First, we can examine whether our belief manipulation has a persisting effect or whether the sheer fact of one repetition aligns donors' beliefs about the likelihood of further continuation. If the manipulation also has an effect in year 2, we expect A-A to generate higher donations than BC-B, in particular among new donors. If participants learn from the repetition that further repetition is likely (independent of what the letter says), we expect that new donors in these treatments will behave similarly. As we will see below, the answer is that we cannot continue to manipulate donors' beliefs. There are no treatment differences for first-time donors. After one actual repetition, beliefs about future repetitions have converged. Second, we can examine whether the predictions of the simple expected utility framework for substitutes continue to hold. For that we can examine the behavior of repeated donors. Given that the beliefs are now aligned, those who gave more in year 1 would now be expected to give less. Here we find, however, that the opposite is true. Year-2 donations are very similar to year-1 donations for repeated donors, that is, year-1 donations crowd in year- 2 donations. This is why we conclude that habit formation is at work. Third, we can check whether we can replicate our year- 1 findings by looking at the first-time asks in 0 - $\mathrm{A}$ and 0 - $\mathrm{B}$. The donations in 0-A are again higher than in 0-B.

\subsection{Results}

Out of 9,221 repeated mail receivers 367 donated on average $€ 58.15$ yielding a return per mailout of $€ 2.31$ and a response rate of $4 \%$. The total amount raised was $€ 21,341.2$, that is, $87 \%$ of the year 1 amount at a quarter of the costs. While the high response rate among donors (36.5\%) is

\footnotetext{
${ }^{14}$ This amount was somewhat higher than the mailing costs. The anonymous lead gift was provided by us.
} 
not surprising, year-1 non-donors still responded at 2.3\%, almost double of the total rate in the previous year speaking for the validity of our selection model.

Table 4: Second year summary statistics

\begin{tabular}{|c|c|c|c|c|c|c|c|c|}
\hline \multirow[t]{2}{*}{ Treatment } & $\begin{array}{c}\text { Number of } \\
\text { recipients }\end{array}$ & $\begin{array}{l}\text { Number of } \\
\text { donations }\end{array}$ & Response rate & $\begin{array}{l}\text { Average positive } \\
\text { donation }\end{array}$ & Median & "Minimum & "Maximum & Return \\
\hline & (1) & $(2)$ & (3) & (4) & (5) & (6) & (7) & (8) \\
\hline \multicolumn{9}{|c|}{ Panel A: past non-donors } \\
\hline A-A & 2,920 & 68 & $\begin{array}{c}0.023 \\
(0.003)\end{array}$ & $\begin{array}{l}48.559 \\
(8.774)\end{array}$ & 25 & 5 & 500 & $\begin{array}{c}1.131 \\
(0.244)\end{array}$ \\
\hline BC-A & 2,937 & 76 & $\begin{array}{c}0.026 \\
(0.003)\end{array}$ & $\begin{array}{l}53.753 \\
(8.130)\end{array}$ & 30 & 5 & 500 & $\begin{array}{c}1.391 \\
(0.262)\end{array}$ \\
\hline BC-B & 2,912 & 58 & $\begin{array}{c}0.020 \\
(0.003)\end{array}$ & $\begin{array}{c}55.948 \\
(10.857) \\
\end{array}$ & 25 & 5 & 500 & $\begin{array}{c}1.115 \\
(0.259) \\
\end{array}$ \\
\hline \multicolumn{9}{|c|}{ Panel B: past donors } \\
\hline A-A & 157 & 57 & $\begin{array}{c}0.389 \\
(0.039)\end{array}$ & $\begin{array}{l}76.721 \\
(9.615)\end{array}$ & 50 & 10 & 400 & $\begin{array}{l}29.809 \\
(4.773)\end{array}$ \\
\hline BC-A & 135 & 39 & $\begin{array}{c}0.304 \\
(0.040)\end{array}$ & $\begin{array}{l}44.805 \\
(7.716)\end{array}$ & 25 & 1 & 250 & $\begin{array}{l}13.608 \\
(2.927)\end{array}$ \\
\hline BC-B & 160 & 59 & $\begin{array}{c}0.394 \\
(0.039)\end{array}$ & $\begin{array}{c}64.356 \\
(10.153)\end{array}$ & 50 & 5 & 500 & $\begin{array}{l}26.200 \\
(4.741)\end{array}$ \\
\hline
\end{tabular}

Notes: Columns 3, 4, and 8: mean, standard error in parentheses; Columns 4 and 8: monetary amounts in Euros; Treatments: Letter before the hyphen - treatment in year 1, letter after the hyphen - treatment in year 2. Treatments B and C in year 1 are pooled, which is denoted by BC. Treatment A: Control; Treatment B: Higher beliefs about the probability of future mailing; Treatment C: Higher beliefs about the probability of future mailing + opt out option.

Table 4 presents raw results — the averages by treatment—subdivided into previous donors and previous non-donors. Table 5 presents the same averages that were obtained from linear regressions (OLS) with the dependent variable being the response, positive donation or donation including zeros and the independent variables being the set of treatment dummies, excluding constants, and corrected for any potential imbalances between samples by including controls for known individual characteristics (demeaned). In Columns 3 and 5 past donations are included as an additional control variable. The bottom panel presents a set of Walt test $p$-values for equality of coefficients in order to test for potential treatment differences. ${ }^{15}$ Note that the subdivision into previous donors and previous non-donors is only justified because we were able to rule out selection effects based on year-1 treatments (see section 3.2). In the Appendix, Table B5, we present results analogous to Table 5 but without the split.

\footnotetext{
${ }^{15}$ Figures A2 and A3 in the Appendix present histograms of donations in different categories by treatment.
} 


\subsubsection{Year-1 non-donors}

In the year-1 non-donor group, we observe no significant differences in giving behavior by treatment, neither in terms of donation amounts nor in terms of the response rate (both in Table 4 and 5). This strongly suggests that beliefs about the future campaigns have now converged and can no longer be manipulated.

\subsubsection{Year-1 donors}

In the group of year-1 donors, we again observe significant differences in the value of positive gifts between treatments. The average positive donation is lowest in BC-A followed by BC-B, and it is highest in the AA group (€47, €61, and €72 respectively after correcting for individual characteristics, Table 5, Column 2). Note that the average in the A-A treatment is very similar to the average in the year-1 A treatment; the range in the BC-A and BC-B treatment also resembles the averages in year-1 B and C treatments. ${ }^{16}$ Individually, we find a strong persistence of donation amounts over time, see Figure 2. The correlation between first- and second-year donations is 0.78 (for those who donated twice). ${ }^{17}$ This persistence cannot be simply explained by individual heterogeneity; for this to apply, we would need (i) to observe large selection effects based on year-1 treatments and (ii) agents to disregard the belief manipulation in year 1 . We rejected both in section 3. In order to control for persistence, we include the value of past donations as an additional control in Table 5, Column 3 (and 5). The result of this exercise is presented in the following. After controlling for past donations, treatment coefficients for past donors drop substantially and become very close to each other. Wald tests of equality of coefficients yield high $p$-values and $\mathrm{R}^{2}$ increases considerably. This means that other than the persistence in donation amounts over time, there are no treatment differences. ${ }^{18}$ Note that the first-year results suggested that repeated donations to the same cause are substitutes. But within the simple expected utility framework for substitutes donors in A-A should now give less than donors in BC-A and BC-B. This is, however, not the case. Instead, we observe that past donations

\footnotetext{
${ }^{16}$ A direct test of year 1 treatment effects persisting into year 2 is provided in Table B6, in which year 1 donors who all received treatment $A$ in year 2 are compared in respect to year 1 treatment $A$. There, we see that the effect of year 1 treatment A on donation value in year 2 is $€ 16$ (Column I) and highly significant, which compares to the effect of $€ 24$ on donation values in year 1 .

${ }^{17}$ For comparison, Adena et al. (2018) find a correlation between rounds of 0.929 in a lab experiment.

18 This conclusion we can also draw from Table B5 in the Appendix, thus not relying in the split into year-1 donors and non-donors.
} 
crowd in future donations. This strongly suggests the importance of habit formation, calling for the behavioral adaptation of our basic model as provided at the end of section 2. Notice again, however, that we cannot make inferences on whether habit formation is anticipated or not. The data are in line with both.

Figure 2: Donation value choices over time

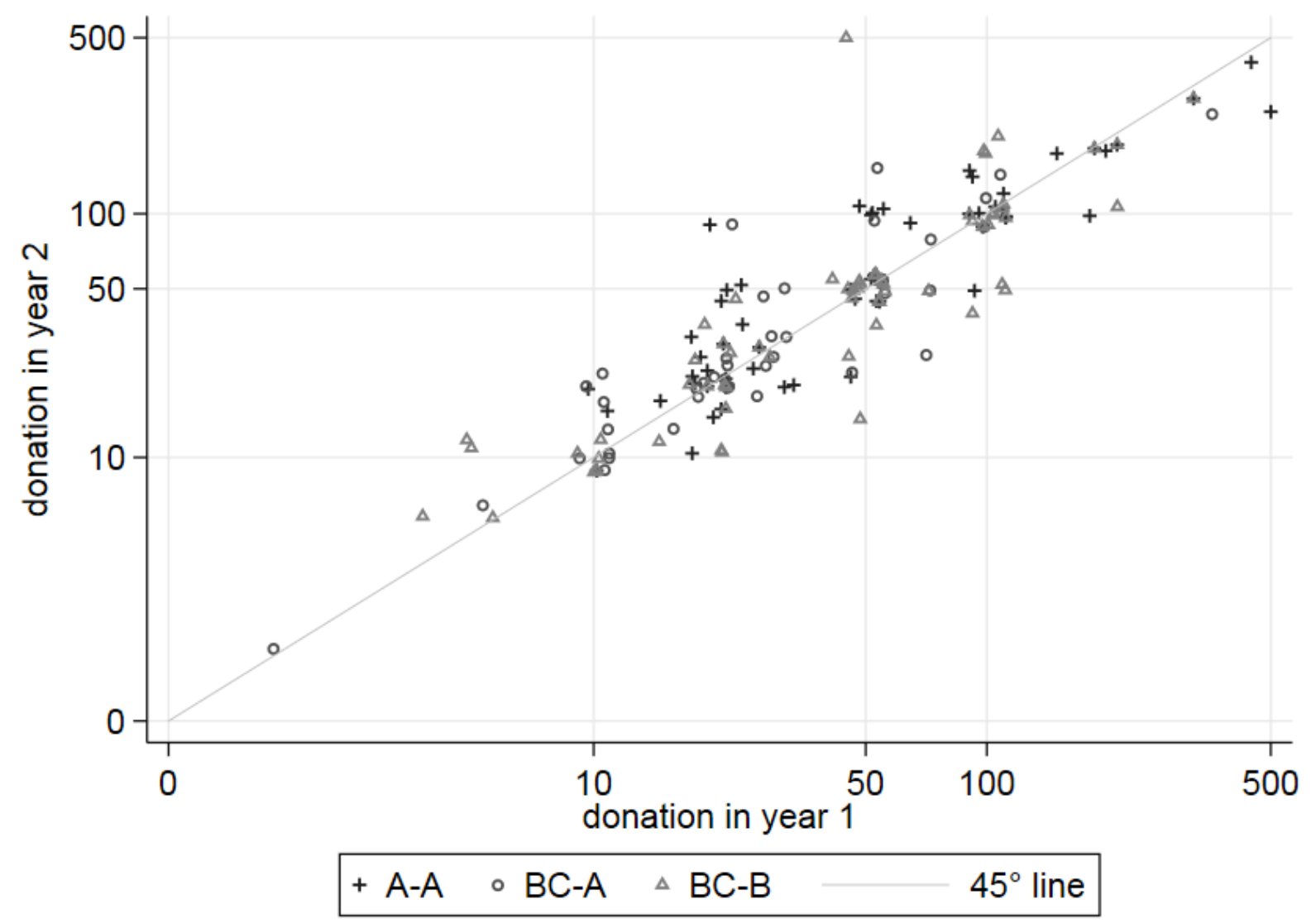

Notes: Scales are in logs; This graph shows the persistence in the choice of donation value over time. It shows only repeated donors. Note that the symbols are slightly jittered in order to increase readability. Treatments: letter before the hyphen treatment in year 1 , letter after the hyphen - treatment in year 2. Treatments B and C in year 1 are pooled, which is denoted by BC. Treatment A: Control; Treatment B: Higher beliefs about the probability of future mailing; Treatment C: Higher beliefs about the probability of future mailing + opt out option.

The response rate in treatment $\mathrm{BC}-\mathrm{A}$ is lowest with $30 \%$ compared to $39 \%$ in the remaining groups. This cannot be explained by our model, nor is there any obvious behavioral bias that would predict such an effect. One possibility is that recipients appreciate consistency of letters and are more likely to respond if identical formats are used, hence A-A would be equally good as B-B. But this remains speculation and despite an extremely low $p$-value the finding may be a 
false positive. As a result, the return from BC-A group is approximately half of that from the A-A and BC-B groups.

Table 5: Second year results

\begin{tabular}{|c|c|c|c|c|c|}
\hline & \multirow{2}{*}{$\begin{array}{c}\text { response } \\
(1) \\
\end{array}$} & \multicolumn{2}{|c|}{ donation } & \multicolumn{2}{|c|}{ return } \\
\hline & & (2) & (3) & (4) & (5) \\
\hline \multicolumn{6}{|l|}{ Past non-donors } \\
\hline A-A & $\begin{array}{c}0.023 \\
(0.003)\end{array}$ & $\begin{array}{l}53.026 \\
(8.512)\end{array}$ & $\begin{array}{l}53.010 \\
(7.402)\end{array}$ & $\begin{array}{c}1.105 \\
(0.330)\end{array}$ & $\begin{array}{c}1.104 \\
(0.321)\end{array}$ \\
\hline BC-A & $\begin{array}{c}0.026 \\
(0.003)\end{array}$ & $\begin{array}{l}49.639 \\
(8.233)\end{array}$ & $\begin{array}{l}50.605 \\
(7.160)\end{array}$ & $\begin{array}{c}1.365 \\
(0.329)\end{array}$ & $\begin{array}{c}1.369 \\
(0.320)\end{array}$ \\
\hline BC-B & $\begin{array}{c}0.019 \\
(0.003) \\
\end{array}$ & $\begin{array}{r}54.033 \\
(9.371) \\
\end{array}$ & $\begin{array}{l}54.287 \\
(8.150) \\
\end{array}$ & $\begin{array}{c}1.097 \\
(0.331) \\
\end{array}$ & $\begin{array}{c}1.093 \\
(0.321) \\
\end{array}$ \\
\hline \multicolumn{6}{|l|}{ Past donors } \\
\hline A-A & $\begin{array}{c}0.397 \\
(0.015)\end{array}$ & $\begin{array}{l}71.808 \\
(9.195)\end{array}$ & $\begin{array}{l}21.867 \\
(9.266)\end{array}$ & $\begin{array}{l}30.144 \\
(1.438)\end{array}$ & $\begin{array}{l}14.888 \\
(1.542)\end{array}$ \\
\hline BC-A & $\begin{array}{c}0.312 \\
(0.016)\end{array}$ & $\begin{array}{c}47.438 \\
(11.574)\end{array}$ & $\begin{array}{c}19.723 \\
(10.395)\end{array}$ & $\begin{array}{l}14.059 \\
(1.547)\end{array}$ & $\begin{array}{c}5.757 \\
(1.544)\end{array}$ \\
\hline BC-B & $\begin{array}{c}0.403 \\
(0.014)\end{array}$ & $\begin{array}{l}61.271 \\
(8.919)\end{array}$ & $\begin{array}{l}22.415 \\
(8.569)\end{array}$ & $\begin{array}{l}26.759 \\
(1.421)\end{array}$ & $\begin{array}{l}16.300 \\
(1.451)\end{array}$ \\
\hline Donation value in year 1 & & & $\begin{array}{c}0.679 \\
(0.064)\end{array}$ & & $\begin{array}{c}0.216 \\
(0.009)\end{array}$ \\
\hline Controls & yes & yes & yes & yes & yes \\
\hline Observations & 9221 & 367 & 367 & 9221 & 9221 \\
\hline$R^{2}$ & 0.186 & 0.485 & 0.611 & 0.097 & 0.147 \\
\hline Past non-donors & \multicolumn{5}{|c|}{ Wald tests of equality of coefficients p-values } \\
\hline $\mathrm{A}-\mathrm{A}=\mathrm{BC}-\mathrm{A}$ & 0.5413 & & 0.8132 & & 0.5597 \\
\hline$B C-A=B C-B$ & 0.1778 & & 0.7296 & & 0.5426 \\
\hline$A-A=B C-B$ & 0.4614 & & 0.9068 & & 0.9791 \\
\hline \multicolumn{6}{|l|}{ Past donors } \\
\hline$A-A=B C-A$ & 0.0001 & & 0.8654 & & 0.0000 \\
\hline$B C-A=B C-B$ & 0.0000 & & 0.8298 & & 0.0000 \\
\hline$A-A=B C-B$ & 0.7666 & & 0.9602 & & 0.4707 \\
\hline \multicolumn{6}{|c|}{$\begin{array}{l}\text { Notes: OLS regressions, no constant, standard errors in parentheses, controls (demeaned) include number of opera tickets, total } \\
\text { spent, average per ticket, female, couple, subscription holder, academic, doctor title, professor title, living in Dresden, Germany, } \\
\text { big city, dummy internet buyer and benefactor circle dummy. Treatments: letter before the hyphen - treatment in year 1, letter } \\
\text { after the hyphen - treatment in year } 2 \text {. Treatments B and C in year } 1 \text { are pooled, which is denoted by BC. Treatment A: Control; } \\
\text { Treatment B: Higher beliefs about the probability of future mailing; Treatment C: Higher beliefs about the probability of future } \\
\text { mailing + opt out option. }\end{array}$} \\
\hline
\end{tabular}




\subsubsection{New recipients}

On top of 367 donations in year 2 from repeated recipients, there were 99 donations from new recipients. Table 6 summarizes the results from year 2 and Figure A4 in the Appendix presents the histogram of donations by treatment. As in year 1 , we do not observe any differences in the response rate which is now at a level of $2.4 \%$. The average positive donation is $€ 152.5$ in the 0 -A treatment and $€ 64$ in the $0-\mathrm{B}$ treatment. The difference between the average positive donation becomes even larger when correcting for individual characteristics in OLS regressions and a Wald test of equality of coefficients rejects equality at 10\% (bottom panel of Table 6, Column 9). In other words, we are able to replicate the year-1 effect.

Table 6: Second year results - new donation ask recipients

Mean, standard error in parentheses

\begin{tabular}{|c|c|c|c|c|c|c|c|c|c|c|c|}
\hline \multirow{3}{*}{ Treatment } & \multirow{3}{*}{$\begin{array}{l}\text { Number } \\
\text { of } \\
\text { recipients } \\
\text { (1) }\end{array}$} & \multirow{3}{*}{$\begin{array}{l}\text { Number } \\
\text { of } \\
\text { donations } \\
\text { (2) }\end{array}$} & \multirow{3}{*}{$\begin{array}{c}\text { Median } \\
\text { (3) }\end{array}$} & \multirow{3}{*}{$\begin{array}{c}\text { Minimum } \\
\text { (4) }\end{array}$} & \multirow{3}{*}{$\begin{array}{c}\text { Maximum } \\
\text { (5) }\end{array}$} & \multicolumn{6}{|c|}{ OLS regressions } \\
\hline & & & & & & \multicolumn{2}{|c|}{ Response rate } & \multicolumn{2}{|c|}{$\begin{array}{c}\text { Average positive } \\
\text { donation }\end{array}$} & \multicolumn{2}{|c|}{ Return } \\
\hline & & & & & & (6) & (7) & (8) & (9) & (10) & (11) \\
\hline $0-\mathrm{A}$ & 2011 & 50 & 42.5 & 10 & 2500 & $\begin{array}{c}0.025 \\
(0.003)\end{array}$ & $\begin{array}{c}0.029 \\
(0.004)\end{array}$ & $\begin{array}{l}152.500 \\
(45.317)\end{array}$ & $\begin{array}{l}147.651 \\
(44.850)\end{array}$ & $\begin{array}{c}3.792 \\
(1.181)\end{array}$ & $\begin{array}{c}3.675 \\
(1.316)\end{array}$ \\
\hline $0-\mathrm{B}$ & 2014 & 49 & 30 & 2 & 500 & $\begin{array}{c}0.024 \\
(0.003)\end{array}$ & $\begin{array}{c}0.029 \\
(0.004)\end{array}$ & $\begin{array}{c}64.020 \\
(45.777)\end{array}$ & $\begin{array}{c}38.169 \\
(45.798)\end{array}$ & $\begin{array}{l}1.558 \\
(1.180)\end{array}$ & $\begin{array}{c}1.492 \\
(1.316)\end{array}$ \\
\hline Controls & & & & & & & yes & & yes & & yes \\
\hline Observations & & & & & & 4025 & 4025 & 99 & 99 & 4025 & 4025 \\
\hline $\mathrm{R}^{2}$ & & & & & & 0.025 & 0.029 & 0.120 & 0.275 & 0.003 & 0.007 \\
\hline $\begin{array}{l}\text { Comparison } \\
\text { groups }\end{array}$ & & & & & & \multicolumn{6}{|c|}{ Wald tests of equality of coefficients p-values } \\
\hline $0-A=0-B$ & & & & & & & 0.8811 & & 0.0757 & & 0.1906 \\
\hline
\end{tabular}

Notes: Sample of new customers: no fundraising in the first year (denoted 0-); second year treatments: A: Control; B: Higher beliefs about the probability of future mailing. Columns 6-11: results from linear regressions with and without controls, excluding constant. The coefficients in Columns 6, 8, and 10 are equivalent to raw averages; The coefficients in Columns 7, 9, and 11 are corrected averages per treatment. Controls (demeaned) include number of opera tickets, total spent and average per ticket in the year prior to the mailing; dummy for internet customer and new customer dummy. 


\section{Conclusion}

Our study examines intertemporal crowding in fundraising for the same charitable project in two subsequent field experiments. We show that, on the inception of a new fundraising drive, increasing the likelihood of future calls decreases donations (we replicate this result with new letter recipients in year 2). At the same time, we show that, in the subsequent fundraising call, donations are similar to those in the first call. This cannot be explained by a simple expected utility framework, which would require substitutability between multiple donations for the first result and complementarity for the second. Rather, our results are in line with a behavioral adaptation of the simple expected utility model that (i) accounts for habit formation and (ii) assumes repeated donations are substitutes.

In contrast to previous work, we find no evidence for economically meaningful annoyance costs (Damgaard and Gravert 2018). When recipients are made aware of an easy option to unsubscribe from future calls only very few recipients make use of this option and there is no "getting over with it once and for all” as in Kamdar et al. (2015). It appears that opera goers do not mind to receive mail from the opera even if it is for a fundraising campaign for which they do not give. Incidentally, this is in line with Huck and Rasul's (2010) observation that printing a slogan on the envelope that indicates that the envelope contains an ask has no effect on giving in the opera context.

Our main results have implications for both the theory of philanthropy and for practical fundraising purposes. For practical purposes, it becomes clear that the design of an initial campaign has to take future plans carefully into account. It may not be optimal to announce new long-term programs as such and anything that encourages giving in one year (such as substantial lead gifts) may pay off doubly in the future.

From a more theoretical perspective, it appears that generosity is something that is learned and, hence, can perhaps be taught. This is in line with suggestive results by Rosen and Sims (2011), who examine long-term US panel data and find a strong correlation between giving in youth and later adulthood. It is unclear from our data whether donors anticipate their own persistence in giving behavior or surprise themselves with persistence over time. It is also unclear whether the 
habit just applies to a single cause or whether there are spillovers to other causes. It is intriguing to imagine that some form of broader altruistic concerns can be acquired through one-off acts of generosity. Research shedding more light on the dynamic formation of altruistic preferences is needed.

\section{References:}

Adena, Maja. 2014. “Tax-Price Elasticity of Charitable Donations - Evidence from the German Taxpayer Panel.” SP II 2014-302. WZB Discussion Paper.

Adena, Maja, Jeyhun Alizade, Frauke Bohner, Julian Harke, and Fabio Mesters. 2018. “Quality Certifications for Nonprofits, Charitable Giving, and Donor's Trust : Experimental Evidence.” SP II 2017-302r. WZB Working Paper.

Adena, Maja, and Steffen Huck. 2017. "Matching Donations without Crowding out? Some Theoretical Considerations, a Field, and a Lab Experiment.” Journal of Public Economics 148. https://doi.org/10.1016/j.jpubeco.2017.02.002.

Adena, Maja, Steffen Huck, and Imran Rasul. 2014. "Charitable Giving and Nonbinding Contribution-Level Suggestions Evidence from a Field Experiment.” Review of Behavioral Economics 1 (3): 275-93. https://doi.org/10.1561/105.00000010.

Altonji, Joseph G, Todd E Elder, and Christopher R Taber. 2005. "Selection on Observed and Unobserved Variables: Assessing the Effectiveness of Catholic Schools.” Journal of Political Economy 113 (1): 151-84. https://doi.org/10.1086/426036.

Andreoni, James, Justin M Rao, and Hannah Trachtman. 2017. “Avoiding The Ask: A Field Experiment on Altruism, Empathy, and Charitable Giving.” Journal of Political Economy 125 (3): 625-53. https://doi.org/10.1086/691703.

Cairns, Jason, and Robert Slonim. 2011. "Substitution Effects across Charitable Donations.” Economics Letters. Vol. 111. https://doi.org/10.1016/j.econlet.2011.01.028.

Damgaard, Mette Trier, and Christina Gravert. 2018. "The Hidden Costs of Nudging: Experimental Evidence from Reminders in Fundraising.” Journal of Public Economics 157: $15-26$.

DellaVigna, Stefano, John List, and Ulrike Malmendier. 2012. "Testing for Altruism and Social 
Pressure in Charitable Giving.” Quarterly Journal of Economics 127 (1): 1-56. https://doi.org/10.1093/qje/qjr050.

Frey, Bruno S., and Stephan Meier. 2004. "Social Comparisons and Pro-Social Behavior : Testing in a Field Experiment " Conditional Cooperation ".” The American Economic Review 94 (5): 1717-22. https://doi.org/10.1257/0002828043052187.

Huck, Steffen, and Imran Rasul. 2010. “Transactions Costs in Charitable Giving : Evidence from Two Field Experiments.” The B . E . Journal of Economic Analysis \& Policy Advances 10 (1).

—. 2011. "Matched Fundraising: Evidence from a Natural Field Experiment.” Journal of Public Economics 95 (5-6): 351-62. https://doi.org/10.1016/j.jpubeco.2010.10.005.

Kamdar, Amee, Steven D Levitt, John A List, Brian Mullaney, and Chad Syverson. 2015. “Once and Done: Leveraging Behavioral Economics to Increase Charitable Contributions.” 025. SPI Working Paper.

Landry, Craig E, Andreas Lange, Michael K Price, and Nicholas G Rupp. 2010. “Is a Donor in Hand Better Than Two in the Bush? Evidence From a Natural Field Experiment." American Economic Review 100: 437-55.

List, John, Azeem M. Shaikh, and Yang Xu. 2016. “Multiple Hypothesis Testing in Experimental Economics.” NBER Working Paper Series. https://doi.org/10.3386/w21875.

Meer, Jonathan. 2017. “Does Fundraising Create New Giving?” Journal of Public Economics 145: 82-93. https://doi.org/10.1016/j.jpubeco.2016.11.009.

Oster, Emily. 2019. “Unobservable Selection and Coefficient Stability: Theory and Evidence.” Journal of Business and Economic Statistics, forthcoming. https://doi.org/10.1080/07350015.2016.1227711.

Peloza, John, and Piers Steel. 2005. “The Price Elasticities of Charitable Contributions: A MetaAnalysis.” Journal of Public Policy \& Marketing 24 (2): 260-72. https://doi.org/10.1509/jppm.2005.24.2.260.

Rosen, Harvey S., and Stephen T. Sims. 2011. “Altruistic Behavior and Habit Formation.” Nonprofit Management and Leadership 21 (3): 235-53. https://doi.org/10.1002/nml.20023. Scharf, Kimberley, Sarah Smith, and Mark Ottoni-Wilhelm. 2017. "Lift and Shift: The Effect of Fundraising Interventions in Charity Space and Time.” CEPR Discussion Paper No. DP12338. 


\section{Appendix A: Additional Proofs}

We denote the first derivatives of $V$ by $V_{i}$ and the second derivatives by $V_{i j}$ and drop the time index $x_{1}=x_{2}=x$. Using the implicit function theorem on the first-order condition we get

$$
\frac{\partial x}{\partial p}=-\frac{V_{1}(x, x)+V_{2}(x, x)-V_{1}(x, 0)}{p\left(V_{11}(x, x)+V_{22}(x, x)+2 V_{12}(x, x)\right)+(1-p) V_{11}(x, 0)}
$$

We first show that the denominator of this expression is negative for concave $V$ regardless of the sign of $V_{12}$. For this it is sufficient to show that

$$
V_{11}(x, x)+V_{22}(x, x)+2 V_{12}(x, x) \leq 0
$$

Dropping the arguments we re-write this as

$$
V_{11}+V_{22} \leq-2 V_{12}
$$

Squaring both sides we obtain

$$
\text { [A] } \quad V_{11}^{2}+2 V_{11} V_{22}+V_{22}^{2} \geq 4 V_{12}^{2}
$$

From the concavity of $V$ we know that $V_{11} V_{22}>V_{12}^{2}$. Hence, if we substitute $V_{11} V_{22}$ in condition [A] by $V_{12}^{2}$, we obtain the sufficient condition

$$
\text { [B] } \quad V_{11}^{2}+V_{22}^{2} \geq 2 V_{12}^{2}
$$

Now we substitute $V_{12}^{2}$ in condition [B] by $V_{11} V_{22}$ which still preserves sufficiency and obtain after subtracting the right-hand side

$$
\text { [C] }\left(V_{11}-V_{22}\right)^{2} \geq 0
$$

which always holds.

Hence, the sign of $\frac{\partial x}{\partial p}$ depends solely on the sign of the numerator. For complements the sign of the numerator is unambigously positive, that is, the model with anticipated habit formation would predict $\frac{\partial x}{\partial p}>0$. Consequently, the model can only be brought into line with the data for substitutes (in which case one can also conclude that $V_{22}$ cannot be too large). 


\section{Appendix B: Additional Figures and Tables}

\section{Table B1: Results of randomization in year 1}

\begin{tabular}{|c|c|c|c|c|c|c|c|c|c|}
\hline \multirow{3}{*}{$\begin{array}{l}\text { Treatment } \\
\mathrm{N} \\
\text { variable }\end{array}$} & \multirow{2}{*}{\multicolumn{2}{|c|}{$\begin{array}{c}\text { A } \\
11,903\end{array}$}} & \multirow{2}{*}{\multicolumn{2}{|c|}{$\begin{array}{c}\text { B } \\
11,902\end{array}$}} & \multirow{2}{*}{\multicolumn{2}{|c|}{$\begin{array}{c}C \\
11,900\end{array}$}} & \multicolumn{3}{|c|}{ Comparison groups } \\
\hline & & & & & & & $A=B$ & $A=C$ & $\mathrm{~B}=\mathrm{C}$ \\
\hline & mean & $\begin{array}{l}\text { Std. } \\
\text { error }\end{array}$ & mean & $\begin{array}{l}\text { Std. } \\
\text { error }\end{array}$ & mean & $\begin{array}{l}\text { Std. } \\
\text { error }\end{array}$ & \multicolumn{3}{|c|}{ t-test p-value } \\
\hline $\begin{array}{l}\text { Total value of } \\
\text { tickets }\end{array}$ & 215,019 & 2,006 & 213,359 & 2,037 & 213,451 & 1,846 & 0,561 & 0,565 & 0,973 \\
\hline Number of tickets & 3,893 & 0,043 & 3,849 & 0,040 & 3,878 & 0,040 & 0,457 & 0,799 & 0,617 \\
\hline Average price & 65,017 & 0,302 & 65,179 & 0,298 & 65,209 & 0,302 & 0,704 & 0,653 & 0,943 \\
\hline abo & 0,107 & 0,003 & 0,107 & 0,003 & 0,108 & 0,003 & 0,968 & 0,918 & 0,950 \\
\hline female & 0,496 & 0,005 & 0,496 & 0,005 & 0,496 & 0,005 & 0,933 & 0,985 & 0,918 \\
\hline couple & 0,002 & 0,000 & 0,001 & 0,000 & 0,001 & 0,000 & 0,369 & 0,736 & 0,573 \\
\hline academic & 0,045 & 0,002 & 0,045 & 0,002 & 0,045 & 0,002 & 0,976 & 0,956 & 0,932 \\
\hline $\mathrm{PhD}$ & 0,040 & 0,002 & 0,040 & 0,002 & 0,040 & 0,002 & 0,975 & 0,998 & 0,976 \\
\hline Professor & 0,006 & 0,001 & 0,006 & 0,001 & 0,005 & 0,001 & 1,000 & 0,872 & 0,872 \\
\hline Dresden & 0,227 & 0,004 & 0,227 & 0,004 & 0,227 & 0,004 & 0,960 & 0,989 & 0,971 \\
\hline Germany & 0,964 & 0,002 & 0,964 & 0,002 & 0,963 & 0,002 & 0,944 & 0,890 & 0,835 \\
\hline Big city & 0,416 & 0,005 & 0,416 & 0,005 & 0,416 & 0,005 & 0,975 & 0,992 & 0,983 \\
\hline Distance in km & 207,486 & 1,718 & 208,374 & 1,722 & 209,036 & 1,718 & 0,715 & 0,524 & 0,785 \\
\hline Online customer & 0,526 & 0,005 & 0,526 & 0,005 & 0,526 & 0,005 & 0,963 & 0,988 & 0,951 \\
\hline
\end{tabular}

Table B2: statistical tests for treatment differences in Table 1

\begin{tabular}{|c|c|c|c|c|c|c|}
\hline $\begin{array}{l}\text { Comparison } \\
\text { between groups }\end{array}$ & Type of test & Response rate & $\begin{array}{c}\text { Average positive } \\
\text { donation }\end{array}$ & Median & Return & Unsubscription rate \\
\hline \multirow[t]{4}{*}{$\mathrm{A}=\mathrm{B}$} & Equality of means (t-test) & & 0.025 & & 0.031 & \\
\hline & Mann-Whitney U (MWU) test & & 0.168 & & 0.640 & \\
\hline & Test of proportions & 0.647 & & & & 0.467 \\
\hline & Median test & & & 0.243 & & \\
\hline \multirow[t]{4}{*}{$A=C$} & Equality of means (t-test) & & 0.014 & & 0.014 & \\
\hline & Mann-Whitney U (MWU) test & & 0.002 & & 0.513 & \\
\hline & Test of proportions & 0.528 & & & & 0.000 \\
\hline & Median test & & & 0.074 & & \\
\hline \multirow[t]{4}{*}{$B=C$} & Equality of means (t-test) & & 0.555 & & 0.570 & \\
\hline & Mann-Whitney U (MWU) test & & 0.079 & & 0.852 & \\
\hline & Test of proportions & 0.862 & & & & 0.000 \\
\hline & Median test & & & 0.376 & & \\
\hline
\end{tabular}

Notes: p-values of respective tests. 
Figure B1: Shares of donations in different categories in different treatments in year 1

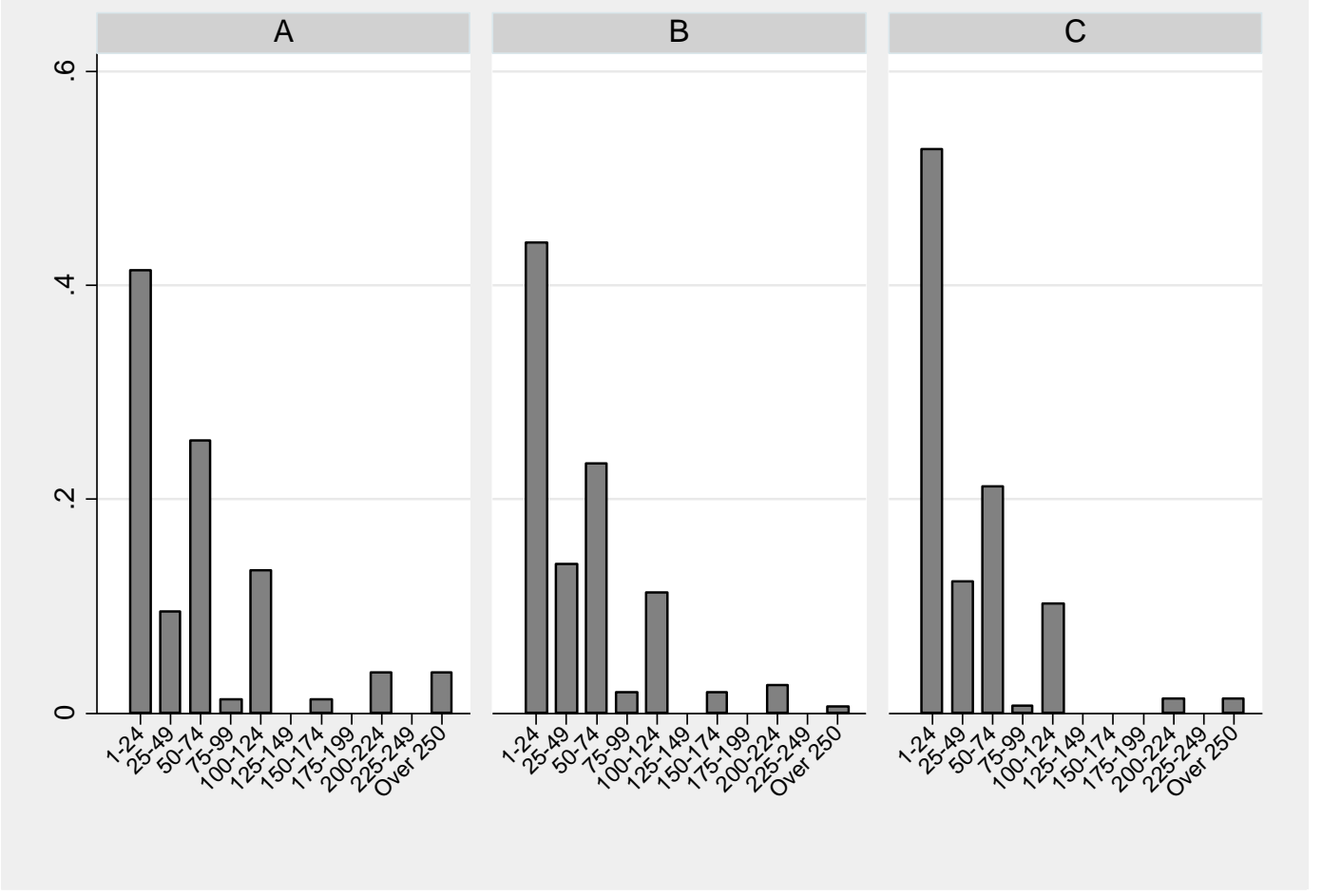

Notes: Treatment A: Control; Treatment B: Higher beliefs about the probability of future mailing; Treatment C: Higher beliefs about the probability of future mailing + opt out option.

\section{Selection procedure and assignment to treatments in year 2}

Using the known characteristics of the opera goers and their responses in year 1 we predicted a donation value for each individual. The twenty-five percent with the highest imputed donation plus all previous donors were included in the new campaign. The final prediction was based on an OLS regression of log of donations (plus one) on several available characteristics. The characteristics included: number of opera tickets, total spent, average per ticket, female, couple, subscription holder, academic, doctor title, professor title, living in Dresden, Germany, big city, dummy internet buyer and benefactor circle. The independent variables were chosen using a lasso selection procedure. We also tested other regression methods like tobit or probit, or more advanced specifications, including higher order polynomials, but no alternative performed obviously better than our chosen OLS in predicting actual donors to be in the top 25\% of the previous sample (around 50\%). All selected individuals from year-1 treatment A received treatment $\mathrm{A}$ again (now denoted A-A). We pooled individuals from the previous treatments B and C, selected the top 25\%. Then we ordered individuals by predicted donation value, and within 
each pair, we randomly selected one individual to receive treatment A (now denoted BC-A), and the other to receive treatment $B$ (now denoted BC-B). Table A3 shows the numbers of individuals allocated to different treatments.

Table B3: Allocation of individuals from treatments in year 1 to treatments in year 2

\begin{tabular}{|l|l|l|l|l|l|}
\hline & \multicolumn{4}{|l|}{ Year-2 treatments } & \\
\hline \multirow{4}{*}{ Year-1 non-donors } & Year-1 treatments & AA & BA & BB & Total \\
\cline { 2 - 6 } & $\mathrm{A}$ & 2.920 & 0 & 0 & 2.920 \\
\cline { 2 - 6 } & $\mathrm{B}$ & 0 & 1.459 & 1.463 & 2.922 \\
\cline { 2 - 6 } & $\mathrm{C}$ & 0 & 1.478 & 1.449 & 2.927 \\
\cline { 2 - 6 } & Total & 2.920 & 2.937 & 2.912 & 8.769 \\
\hline \multirow{5}{*}{ Year-1 non-donors } & $\mathrm{A}$ & 157 & 0 & 0 & 157 \\
\cline { 2 - 6 } & $\mathrm{B}$ & 0 & 77 & 73 & 150 \\
\cline { 2 - 6 } & $\mathrm{C}$ & 0 & 58 & 87 & 145 \\
\cline { 2 - 6 } & Total & 157 & 135 & 160 & 452 \\
\hline & $\begin{array}{l}\text { Total year-1 non- } \\
\text { donors and donors }\end{array}$ & 3077 & 3072 & 3072 & 9221 \\
\hline
\end{tabular}

Note that the slightly unequal number of selected non-donors results from the fact that the top 3.000 (25\%) with the highest predicted donation included a different number of past donors. The selection procedure took top 3.000 plus any remaining donors.

The treatment assignment ensures that the selected individuals are similar between treatments. This is confirmed in Table 3 for the sample of year- 1 donors and in Table A4 for the sample of year-1 non-donors (in the second case we perform 42 separate t- tests and observe only one pvalue below $5 \%$ and one below 10\%).

Table B4: Balancing of non-donors in year 2

\begin{tabular}{|c|c|c|c|c|c|c|c|c|c|}
\hline \multirow{3}{*}{$\begin{array}{l}\text { Treatment } \\
\mathrm{N} \\
\text { variable }\end{array}$} & \multirow{2}{*}{\multicolumn{2}{|c|}{$\begin{array}{l}\text { A-A } \\
2,920\end{array}$}} & \multirow{2}{*}{\multicolumn{2}{|c|}{$\begin{array}{l}\text { BC-A } \\
2,937\end{array}$}} & \multirow{2}{*}{\multicolumn{2}{|c|}{$\begin{array}{l}\text { BC-B } \\
2,912\end{array}$}} & \multicolumn{3}{|c|}{ Comparison groups } \\
\hline & & & & & & & \multirow[t]{2}{*}{$\mathrm{A}-\mathrm{A}=\mathrm{BC}-\mathrm{A}$} & \multirow{2}{*}{$\begin{array}{l}\text { BC-A =BC-B } \\
\text { t-test p-value }\end{array}$} & \multirow[t]{2}{*}{$A-A=B C-B$} \\
\hline & mean & Std. error & mean & Std. error & mean & Std. error & & & \\
\hline Total value of tickets & 363.680 & 6.583 & 355.466 & 6.287 & 361.080 & 6.396 & 0.367 & 0.531 & 0.777 \\
\hline Number of tickets & 8.060 & 0.139 & 7.795 & 0.124 & 8.094 & 0.132 & 0.155 & 0.098 & 0.860 \\
\hline Average price & 54.234 & 0.614 & 54.781 & 0.606 & 53.817 & 0.603 & 0.527 & 0.260 & 0.628 \\
\hline abo & 0.383 & 0.009 & 0.376 & 0.009 & 0.394 & 0.009 & 0.601 & 0.165 & 0.388 \\
\hline female & 0.478 & 0.009 & 0.476 & 0.009 & 0.478 & 0.009 & 0.873 & 0.897 & 0.975 \\
\hline couple & 0.006 & 0.001 & 0.005 & 0.001 & 0.004 & 0.001 & 0.589 & 0.722 & 0.372 \\
\hline academic & 0.153 & 0.007 & 0.163 & 0.007 & 0.152 & 0.007 & 0.311 & 0.250 & 0.891 \\
\hline $\mathrm{PhD}$ & 0.134 & 0.006 & 0.143 & 0.006 & 0.133 & 0.006 & 0.313 & 0.279 & 0.941 \\
\hline Professor & 0.020 & 0.003 & 0.020 & 0.003 & 0.019 & 0.003 & 0.878 & 0.742 & 0.862 \\
\hline Dresden & 0.616 & 0.009 & 0.620 & 0.009 & 0.616 & 0.009 & 0.737 & 0.736 & 0.998 \\
\hline Germany & 0.994 & 0.001 & 0.994 & 0.001 & 0.996 & 0.001 & 0.879 & 0.200 & 0.259 \\
\hline Big city & 0.671 & 0.009 & 0.674 & 0.009 & 0.668 & 0.009 & 0.769 & 0.612 & 0.832 \\
\hline Distance in km & 68.695 & 2.575 & 69.754 & 2.560 & 66.127 & 2.477 & 0.771 & 0.309 & 0.472 \\
\hline Online customer & 0.057 & 0.004 & 0.049 & 0.004 & 0.061 & 0.004 & 0.223 & 0.049 & 0.454 \\
\hline
\end{tabular}


Table B5: Second year results (donors and non-donors jointly)

\begin{tabular}{|c|c|c|c|c|c|c|c|c|}
\hline & \multicolumn{2}{|c|}{ response } & \multicolumn{3}{|c|}{ donation } & \multicolumn{3}{|c|}{ return } \\
\hline & (1) & (2) & (3) & (4) & (5) & (6) & $(7)$ & (8) \\
\hline A-A & $\begin{array}{c}0.042 \\
(0.004)\end{array}$ & $\begin{array}{c}0.042 \\
(0.004)\end{array}$ & $\begin{array}{l}61.876 \\
(6.505)\end{array}$ & $\begin{array}{c}62.801 \\
(6.275)\end{array}$ & $\begin{array}{l}43.701 \\
(5.887)\end{array}$ & $\begin{array}{c}2.594 \\
(0.335)\end{array}$ & $\begin{array}{c}2.601 \\
(0.335)\end{array}$ & $\begin{array}{c}1.591 \\
(0.317)\end{array}$ \\
\hline BC-A & $\begin{array}{c}0.038 \\
(0.004)\end{array}$ & $\begin{array}{c}0.039 \\
(0.004)\end{array}$ & $\begin{array}{l}50.617 \\
(6.830)\end{array}$ & $\begin{array}{l}49.927 \\
(6.705)\end{array}$ & $\begin{array}{l}42.367 \\
(5.990)\end{array}$ & $\begin{array}{c}1.928 \\
(0.336)\end{array}$ & $\begin{array}{c}1.977 \\
(0.335)\end{array}$ & $\begin{array}{c}1.467 \\
(0.316)\end{array}$ \\
\hline BC-B & $\begin{array}{c}0.039 \\
(0.004)\end{array}$ & $\begin{array}{c}0.039 \\
(0.004)\end{array}$ & $\begin{array}{l}61.463 \\
(6.716)\end{array}$ & $\begin{array}{l}58.726 \\
(6.387)\end{array}$ & $\begin{array}{l}41.997 \\
(5.908)\end{array}$ & $\begin{array}{c}2.421 \\
(0.336)\end{array}$ & $\begin{array}{c}2.435 \\
(0.335)\end{array}$ & $\begin{array}{c}1.723 \\
(0.317)\end{array}$ \\
\hline Donation value in year 1 & & & & & $\begin{array}{c}0.558 \\
(0.056)\end{array}$ & & & $\begin{array}{c}0.272 \\
(0.008)\end{array}$ \\
\hline Controls & & yes & & yes & yes & & yes & yes \\
\hline Observations & 9221 & 9221 & 367 & 367 & 367 & 9221 & 9221 & 9221 \\
\hline$R^{2}$ & 0.040 & 0.046 & 0.386 & 0.481 & 0.594 & 0.015 & 0.024 & 0.132 \\
\hline $\begin{array}{l}A-A=B C-A \\
B C-A=B C-B \\
A-A=B C-B\end{array}$ & & $\begin{array}{l}0.5383 \\
0.9575 \\
0.5740 \\
\end{array}$ & Wald tests & equality & $\begin{array}{c}\text { oefficier } \\
0.8680 \\
0.9635 \\
0.8269\end{array}$ & p-values & & $\begin{array}{l}0.7798 \\
0.5662 \\
0.7685 \\
\end{array}$ \\
\hline
\end{tabular}

Notes: OLS regressions, no constant, standard errors in parentheses, controls (demeaned) include number of opera tickets, total spent, average per ticket, female, couple, subscription holder, academic, doctor title, professor title, living in Dresden, Germany, big city, dummy internet buyer and benefactor circle dummy. Treatments: letter before the hyphen - treatment in year 1, letter after the hyphen - treatment in year 2. Treatments B and C in year 1 are pooled, which is denoted by BC. Treatment A: Control; Treatment B: Higher beliefs about the probability of future mailing; Treatment C: Higher beliefs about the probability of future mailing + opt out option.

Table B6: The effect of year-1 A treatment on donation value in year 2 (year-1 donors who receive treatment $\mathrm{A}$ in year 2 )

\begin{tabular}{lccc}
\hline Dependent variable: & \multicolumn{3}{c}{ Donation value in year 2 } \\
\hline Year-1 A treatment & $16.123^{* * *}$ & $10.060^{*}$ & $20.048^{* * *}$ \\
& $(5.858)$ & $(5.498)$ & $(6.700)$ \\
Donation value in year 1 & & $0.188^{* * *}$ & $0.406^{* * *}$ \\
& & $(0.027)$ & $(0.090)$ \\
Year-1 A treatment x donation value & & & $-0.238^{* *}$ \\
& & & $(0.093)$ \\
\hline Controls & yes & yes & yes \\
\hline Observations & 291 & 291 & 291 \\
$R^{2}$ & 0.071 & 0.206 & 0.224 \\
\hline
\end{tabular}

Notes: The sample includes all year 1 donors who receive treatment A in year 2; Controls: see notes to Table 2;

Standard errors in parentheses; ${ }^{*} p<0.10,{ }^{* *} p<0.05,{ }^{* * *} p<0.01$ 
Figure B2: Share of donations in different categories by past non-donors in different treatments

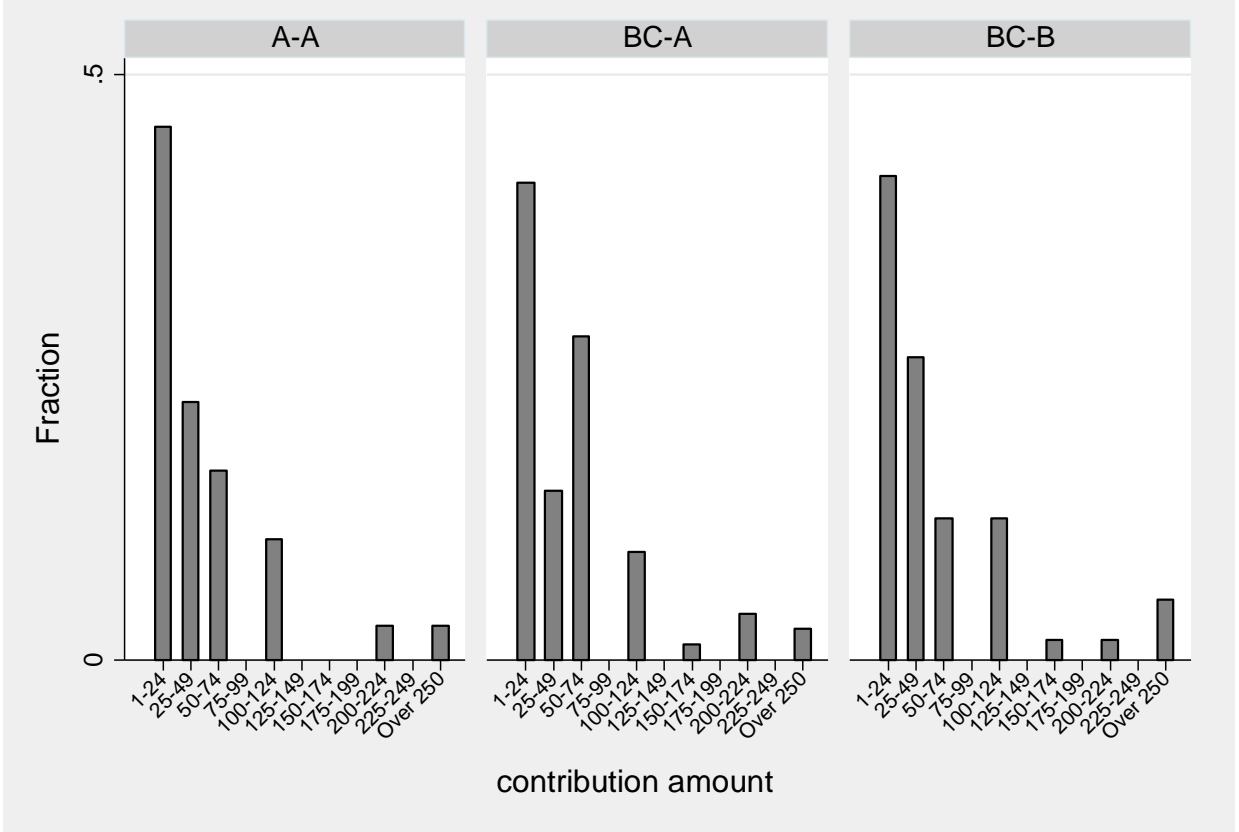

Notes: Treatments: letter before the hyphen - treatment in year 1, letter after the hyphen - treatment in year 2. Treatments B and C in year 1 are pooled, which is denoted by BC. Treatment A: Control; Treatment B: Higher beliefs about the probability of future mailing; Treatment C: Higher beliefs about the probability of future mailing + opt out option.

Figure B3: Share of donations in different categories by past donors in different treatment

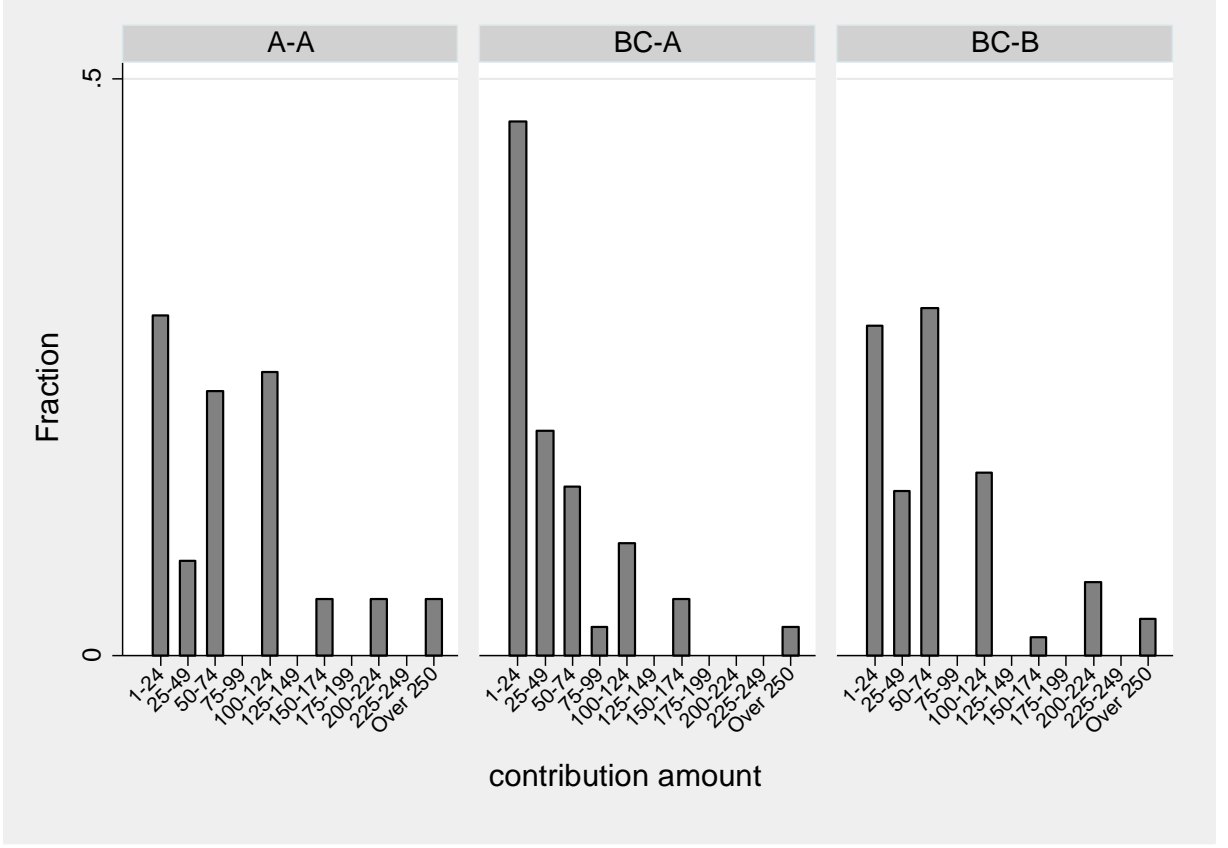

Notes: Treatments: letter before the hyphen - treatment in year 1, letter after the hyphen - treatment in year 2. Treatments B and C in year 1 are pooled, which is denoted by BC. Treatment A: Control; Treatment B: Higher beliefs about the probability of future mailing; Treatment C: Higher beliefs about the probability of future mailing + opt out option. 
Figure B4: Giving in year 2 by nonparticipants in year 1

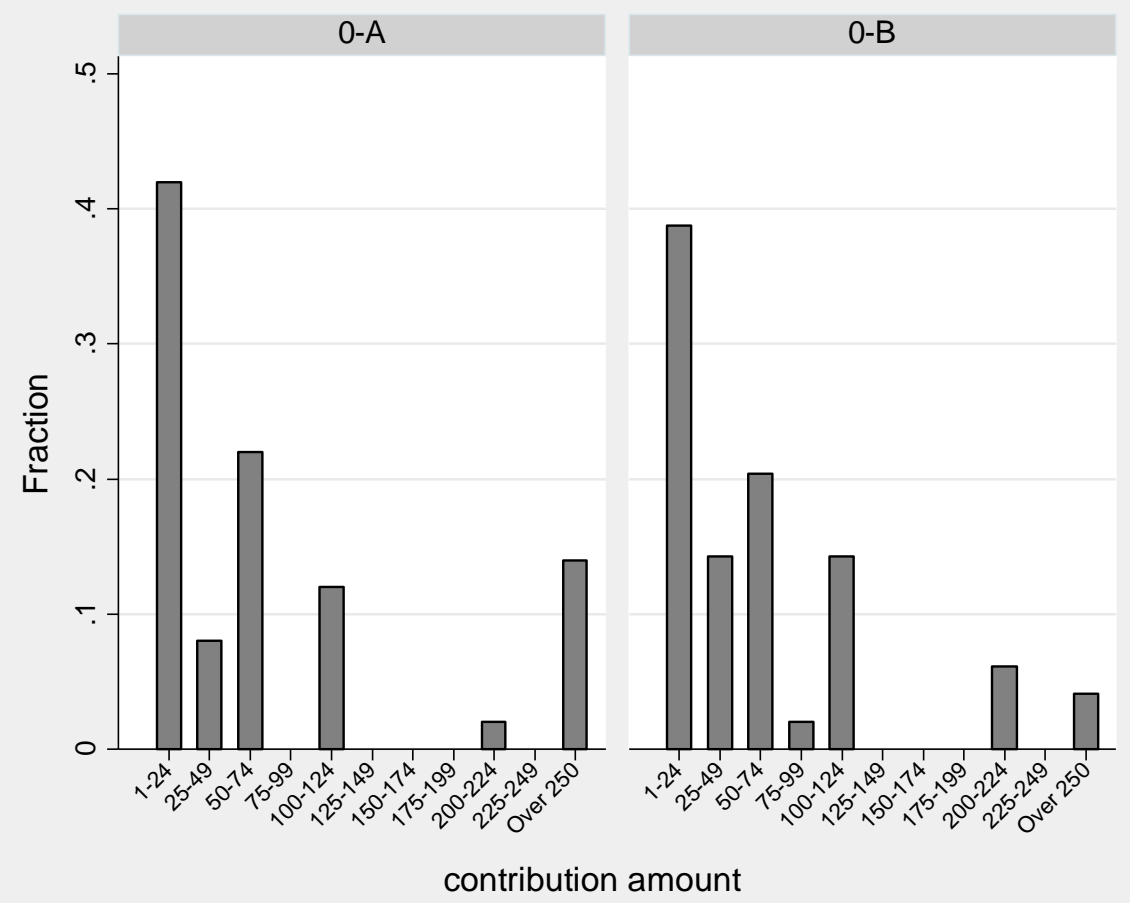

Notes: no fundraising in the first year (denoted 0-); second year treatments: A: Control; B: Higher beliefs about the probability of future mailing. 


\section{Appendix C: Mailing details}

\section{Mail-out: original 2015}

The additional words in B and C are in square brackets, the additional footnote in C is in curled brackets. The letter contained an additional page with information about the project that was equal across treatments and therefore is not presented here.

Dresden, 18.11.2015

Sehr geehrter Herr ,

\section{[Premiere:}

\section{Erster] Spendenaufruf}

Semperoper Junge Szene

\section{Ihre Kundennummer \\ 10123456}

Intendant Staatsoper (kommissarisch) \&

Kaufmännischer Geschäftsführer

$\mathrm{XXX}$

T 0351 XXX

F 0351 XXX

XX@saechsische-staatstheater.de es ist der Semperoper Jungen Szene ein großes Anliegen, jungen Menschen mit altersgerechten Angeboten die faszinierende Welt des Musiktheaters und die damit verbundenen Chancen [dauerhaft] zu eröffnen. Insbesondere mit den theaterpädagogischen Veranstaltungen fühlen wir uns den Themen Nachwuchsförderung, Nachhaltigkeit und gesellschaftliche Verantwortung verpflichtet und möchten [langfristig] wichtige Workshops und Projekte mit dem Schwerpunkt Inklusion und Integration anbieten.

Da für derartige Projekte kaum eigene Mittel aus dem Haushaltsetat zur Verfügung stehen, ist die Semperoper Junge Szene hierbei [jedes Jahr aufs Neue] überwiegend auf Ihre Spende angewiesen.

Helfen auch Sie mit Ihrer Spende [im Jahr 2015]! Dadurch tragen Sie entscheidend zur Entwicklung von musikalischer Bildung und Begeisterung für Oper und Musik junger Menschen bei, unabhängig von deren sozialem Hintergrund. Darüber hinaus unterstützen Sie die Stärkung sozialer Kompetenzen vieler Kinder aus verschiedenen gesellschaftlichen Milieus und Nationen.

Wir freuen uns, Ihnen mitteilen zu können, dass ein Geber, der anonym bleiben möchte, bereits gewonnen werden konnte. Er unterstützt die Junge Szene [in diesem Jahr] mit 15.000 Euro.

Als Dankeschön verlosen wir unter allen Spendern einen Besuch der Vorstellung »Lohengrin« mit Anna Netrebko im Mai 2016 für zwei Personen in der Intendantenloge.

Herzlichen Dank für Ihre Unterstützung [im Jahr 2015]!

Mit freundlichen Grüßen

\section{XXX}

Intendant Staatsoper (kommissarisch)

und Kaufmännischer Geschäftsführer

\{P.S. Falls Sie in der Zukunft keine weiteren Spendenanfragen der Semperoper erhalten möchten, teilen Sie uns dies bitte unter Angabe Ihrer Kundennummer mit: XXX@semperoper.de oder 0351 XXX\} 
Mail-out: Translation 2015

The additional words in B and $\mathrm{C}$ are in square brackets, the additional footnote in $\mathrm{C}$ is in curled brackets. The letter contained an additional page with information about the project that was equal across treatments and therefore is not presented here.

Dresden, 18.11.2015

Dear Sir /Madam,

[Premiere:

First] call for donations

Semperoper Junge Szene

Your customer number

10123456

Director Staatsoper (temporarily)

and Commercial manager

XXX

T 0351 XXX

F 0351 XXX

XX@saechsische-staatstheater.de
The Semperoper Junge Szene attaches great importance to [permanently] opening up the fascinating world of music theatre and the associated opportunities to young people with age-group-specific projects. Especially with our educational theatre events, we feel committed to the topics of youth development, sustainability and societal responsibility and aim at offering important workshops and projects with a focus on inclusion and integration [over the long term].

Due to the lack of resources from our own budget for projects of this kind, the Semperoper Junge Szene relies [year by year] heavily on your donations.

Help us by donating [in the year 2015]! In doing so, you will contribute decisively to the future development of musical education and enthusiasm for the opera and music among young people, irrespective of their social background. In addition, you will help many children from different social milieus and nations to strengthen their social skills of.

We are pleased to inform you that we have managed to attract a donor who wishes to remain anonymous for the project. He is supporting the Junge Szene to the tune of 15,000 Euro [this year].

As a thank you for taking part, all donors will be entered into a draw and the winner will get 2 tickets for the show "Lohengrin” with Anna Netrebko in May 2016 for 2 persons in the director’s loge.

Many thanks for your support [in the year 2015]!

Sincerely

XXX

Director Staatsoper (temporarily)

and Commercial manager

\{P.S. In case you do not wish to receive any further donation inquiries for the Semperoper in the future, please inform us, stating your customer number: XXX@semperoper.de or 0351 XXX\} 


\section{Mail-out: original 2016}

The additional words in B are in square brackets. The letter contained an additional page with information about the project that was equal across treatments and therefore is not presented here.

Dresden, 29.11.2016

\section{[Wiederaufnahme: \\ Zweiter] Spendenaufruf}

\section{Ihre Kundennummer 10123456}

Intendant Staatsoper (kommissarisch) \&

Kaufmännischer Geschäftsführer

XXXX

T 0351 XXX

F 0351 XXX

XX@saechsische-staatstheater.de
Sehr geehrter

die Semperoper engagiert sich seit vielen Jahren durch Projekte der Jungen Szene auch für die Förderung von Kindern und Jugendlichen aus einem gesellschaftlich benachteiligten Umfeld, um ihnen [dauerhaft] die spannende Welt der Oper erlebbar und zugänglich zu machen.

Da wir gesellschaftliche Verantwortung sehr ernst nehmen, wollen wir künftig noch einen Schritt weiter gehen, indem wir Kindern aus diesen benachteiligten Milieus gemeinsam mit ihren Familien [langfristig] den Zugang zu Vorstellungen in der Semperoper ermöglichen wollen.

Da uns für derartige Vorhaben keine eigenen Mittel zur Verfügung stehen, ist die Semperoper hierbei [jedes Jahr aufs Neue] auf Ihre Spende angewiesen.

Helfen auch Sie mit Ihrer Spende [im Jahr 2016]! Ihre Spende leistet einen Beitrag zur Verminderung von sozialer Ungleichheit. Sie ermöglicht den Kindern aus benachteiligten Milieus und ihren Familien den Zugang zu kultureller Bildung. Sie trägt dazu bei, musikalische Neugier und die Begeisterung für Oper, Musik und Tanz zu wecken.

Wir freuen uns, Ihnen mitteilen zu können, dass ein Geber, der anonym bleiben möchte, bereits gewonnen werden konnte. Sein Beitrag in Höhe von EUR 10.000 deckt bereits [in diesem Jahr] die Verwaltungskosten, so dass jede Spende den Kindern direkt zugutekommen wird.

Als Dankeschön verlosen wir unter allen Spendern einen Vorstellungsbesuch für zwei Personen in meiner Loge sowie 5 DVDs (Carl Maria von Weber »Der Freischütz«, Christian Thielemann, 2015).

Herzlichen Dank für Ihre Unterstützung!

Mit freundlichen Grüßen

XXX

Intendant Staatsoper (kommissarisch)

und Kaufmännischer Geschäftsführer 


\section{Mail-out: Translation 2016}

The additional words in B are in square brackets. The letter contained an additional page with information about the project that was equal across treatments and therefore is not presented here.

Dresden, 29.11.2016

\section{[renewal:}

second] call for donations

\section{Your customer number}

10123456

Director Staatsoper(temporarily) and

Commercial manager

XXXX

T 0351 XXX

F 0351 XXX

XX@saechsische-staatstheater.de
Dear Sir / Madam,

The Semperoper has for many years been committed, through projects of the Jungen Szene, to support children and young people from a socially disadvantaged context, to [permanently] enable them to experience and access the exciting world of opera.

As we are taking social responsibility very seriously, we want to go even further by giving children from these disadvantaged milieus together with their families [longterm] access to performances at the Semperoper.

Since we have no funds of our own available for such projects, the Semperoper is dependent on your donation [every year].

Please help with your donation [in 2016]! Your donation contributes to the reduction of social inequality. It allows children from disadvantaged backgrounds and their families access to cultural education. It helps to evoke musical curiosity and the enthusiasm for opera, music and dance.

We are pleased to inform you, that a donor, who wants to remain anonymous, could already be won. His contribution of EUR 10,000 already covers the administrative costs [in this year], so that every donation will directly benefit the children.

As a thank you, we raffle an opera visit for two people in my box as well as 5 DVDs among all donors (Carl Maria von Weber "Der Freischütz", Christian Thielemann, 2015).

Thank you for your support!

Sincerely

XXX

Director Staatsoper (temporarily)

and Commercial manager 
Flyer 2015 original:

\section{Die Junge Szene der Semperoper Dresden}

Das Angebot der Semperoper Jungen Szene thematisiert in der aktuellen und der kommenden Spielzeit das Spannungsfeld zwischen Fremdbestimmung und Selbstbehauptung, zwischen Egoismus und sozialer Verantwortung.

Das »Cochlear-Ferienprojekt « für schwerhörige und hörende Kinder und der Integrationsworkshop »Telling Stories - Fremd sein! - Wie gehe ich mit Fremden um? « sind ein wichtiger Bestandteil der Integrations- und Inklusionsarbeit der Semperoper Jungen Szene. Mit den theater-, tanz- und gesangspädagogischen Projekten, wie dem »Spielclub für Kinder« und der Neugründung eines »szenischen Jugendchores« sollen die Formate zum Thema kulturelle Bildung und soziale Integration weiter entwickelt werden.
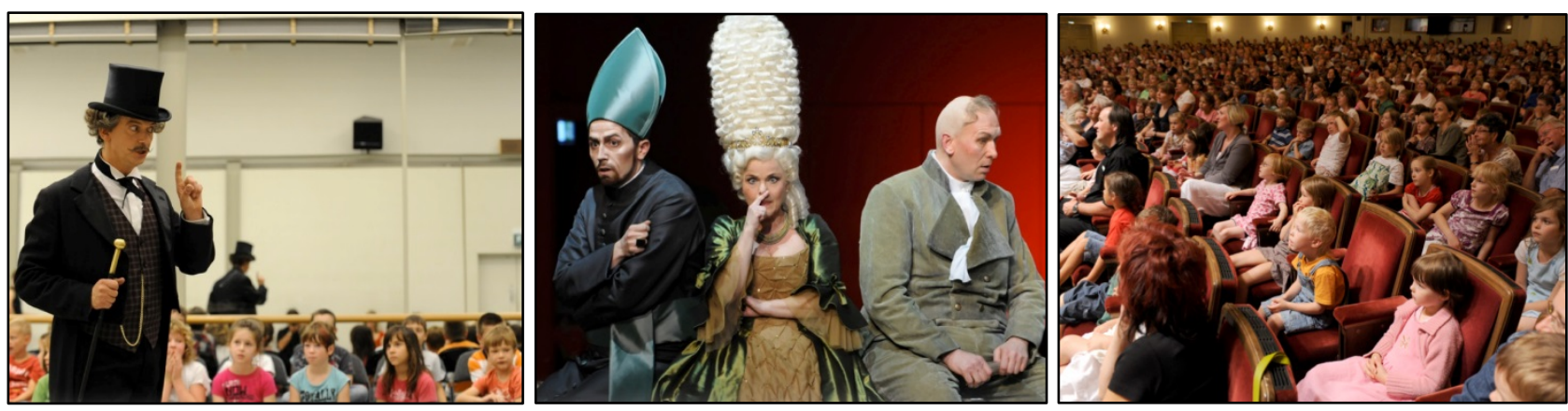

Kinder und Jugendliche sind eingeladen, sich in die aufregende Welt des Musiktheaters zu stürzen. Denn die Erfahrung zeigt: Sie tun dies mit Begeisterung. Viele Kinder und Jugendliche nehmen jede Spielzeit am vielseitigen Angebot des Programms der Semperoper Jungen Szene teil, das gezielt auf die Bedürfnisse junger Menschen eingeht. Das Team der Jungen Szene arbeitet dabei eng mit Schulklassen alle Schulformen zusammen. Die große Resonanz zeigt, wie wichtig es ist, die Phantasie und Kreativität junger Menschen zu fördern und ihre Neugier auf die Welt der Oper zu unterstützen. Wir sind auf Ihre Mithilfe angewiesen, um dieses Angebot fortsetzen und erweitern zu können.

\section{Helfen auch Sie und ermöglichen Sie weiteren Kindern die Teilnahme an den Projekten der Jungen Szene!}

\section{Gewinnen Sie}

einen Besuch der Vorstellung »Lohengrin« mit Anna Netrebko im Mai 2016 für 2 Personen in der Intendantenloge.

\section{Ihre Spende}

Falls Sie nicht den beigefügten Überweisungsträger verwenden, überweisen Sie Ihre Spende bitte auf folgendes Konto:

Empfänger: Sächsische Staatsoper Dresden

$$
\text { XXX Sparkasse XXX }
$$

IBAN: $\quad \mathrm{XXX}$

BIC: $\quad$ XXX

Stichwort: $\quad$ Spende Semperoper Junge Szene: Ihre Kundennummer

\section{Spendenquittung}

Sie erhalten eine Spendenquittung ab einer Spende von € 50,-. Falls diese an eine andere Adresse als im Briefkopf angegeben gesendet werden soll, wenden Sie sich bitte an das Development-Büro unter Tel. XXX. 
Flyer 2015 translation:

\section{The Junge Szene of the Semperoper Dresden}

The offer of the Semperoper Junge Szene (Semeroper young scene) focuses, in the current and coming season, on the central theme of tension between heteronomy and self-determination, between selfishness and social responsibility.

The »Cochlear-Ferienprojekt« (Cochlear holiday project) for children with and without hearing impairments and the integrational workshop »Telling Stories - Be Different! - How do I deal with strangers? « are an important part of the integration and inclusion work of the Semperoper Junge Szene. Theater, dance and vocal pedagogic projects, such as the »Spielclub für Kinder« (Children's Play Club) and the founding of a new »scenic youth choir«, will further develop our formats of cultural education and social integration.

Children and young people are invited to plunge into the exciting world of the musical theater. Because experience shows: that they do so with enthusiasm. Every season, many children and adolescents take part in the varied program of the Semperoper Junge Szene, which focuses specifically on the needs of young people. The team of the Junge Szene cooperates closely with school classes of all school forms. The great response shows how important it is to promote the imagination and creativity of young people and to support their curiosity in the world of opera. To continue and expand this offer we require your support.

\section{Please help and \\ enable more children to benefit from the participation in the projects by the Junge Szene!}

\section{You can win}

a visit of the performance »Lohengrin« with Anna Netrebko on Mai 2016 Mai for two people in the box of the creative director.

\section{Your donation}

Unless you are using the attached transfer form, please transfer your donation to the following account:

Recipient: $\quad$ Sächsische Staatsoper Dresden

XXXX Sparkasse

IBAN: $\quad$ XXXXXX

BIC: $\quad$ XXXX

Purpose: $\quad$ Spende Semperoper Junge Szene: Ihre Kundennummer

\section{Donation receipt}

You will be send a receipt for every donation larger than $€ 50$,- In case you need the receipt to be send to a different address than in the letterhead please contact Development-Office at Tel. XXXX 
Flyer 2016 original:

\section{Gesellschaftliche Verantwortung und Nachhaltigkeit}

Operninszenierungen eröffnen neue Gedankenräume, machen Unsagbares sicht- und hörbar und laden den Zuschauer jeden Abend ein, einen neuen Kosmos mit allen Sinnen zu erleben. Kinder haben die Gabe in diese Welten ganz unbedarft einzutauchen und mit den Figuren auf der Bühne die Reise durch die Handlung mitzuerleben. Nach und nach lernen sie die Sprache des Theaters, die Sprache der Bilder und der Bewegung kennen. Wer als Kind die Möglichkeit hatte, diese Welten kennenzulernen, behält sein Leben lang die dadurch geweckte Neugier, Kreativität und Kritikfähigkeit.

Leider ist der Zugang zum Musiktheater bis heute abhängig vom sozialen Umfeld der Kinder. Wer nicht das Glück hat, mit der Schule in die Oper zu gehen, dem bleibt häufig die faszinierende Welt des Musiktheaters verwehrt.

Dabei könnte der gemeinsame Vorstellungsbesuch der Familie ein Höhepunkt im Familienleben sein und Eltern und Kinder dazu anregen sich über das Erlebte auszutauschen.

Oper sollte unabhängig von sozialer Herkunft und Haushalteinkommen ein Gut für Alle sein, eine Möglichkeit im Kreise der Familie seine Freizeit zu gestalten.

Aus diesem Grund möchten wir insbesondere Kindern und deren Familien aus benachteiligen sozialen Milieus den Zugang zu den Vorstellungen der Semperoper ermöglichen.

Der familienübergreifende Aspekt ist wichtig, um Schwellenängste abzubauen, sozialer Ungerechtigkeit entgegen zu wirken und die Begeisterung für das Musiktheater umfassend und nachhaltig in der Familie zu etablieren.
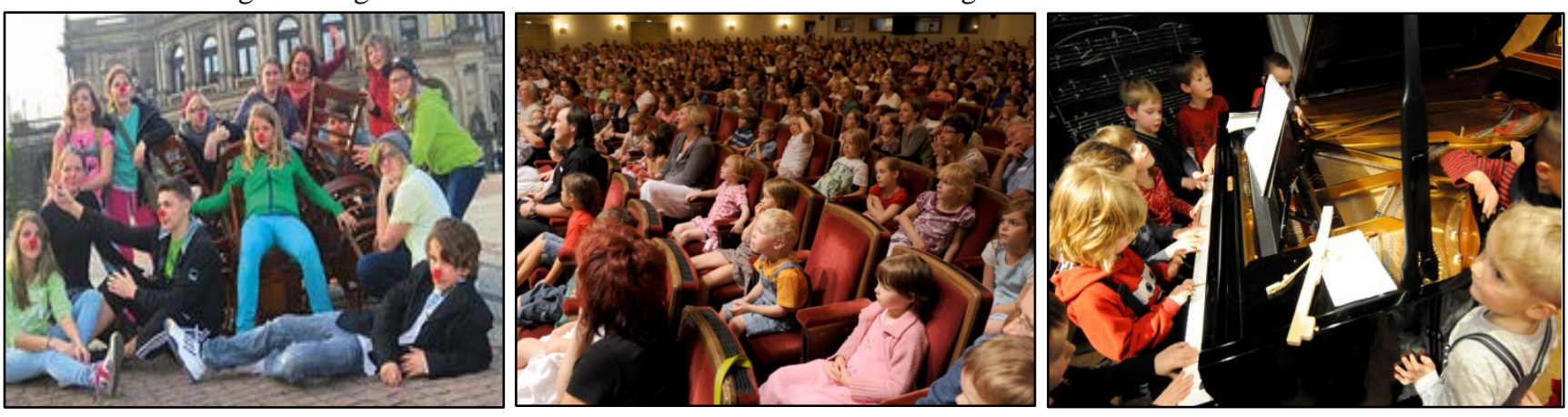

\section{Helfen auch Sie und ermöglichen Sie \\ Kindern und ihren Familien den Besuch einer Opern- oder Ballettvorstellung in der Semperoper!}

\section{Gewinnen Sie}

einen Opernbesuch in der Intendantenloge für 2 Personen oder

eine von 5 DVDs der 2015 in der Semperoper aufgezeichneten Inszenierung von »Der Freischütz« (Musikalische Leitung: Christian Thielemann).

\section{Ihre Spende}

Falls Sie nicht den beigefügten Überweisungsträger verwenden, überweisen Sie Ihre Spende bitte auf folgendes Konto:

Empfänger: Sächsische Staatsoper Dresden XXX Sparkasse XXX

IBAN: $\quad$ XXXX

BIC: $\quad$ XXXX

Stichwort: $\quad$ Spende Familienförderung + Ihre Kundennummer

\section{Spendenquittung}

Gerne stellen wir Ihnen ab einer Spende von $€$ 200,- eine Spendenquittung aus (bis zu dieser Spendenhöhe ist der Überweisungs- oder Einzahlungsbeleg ausreichend). Falls diese an eine andere Adresse als im Briefkopf angegeben gesendet werden soll, wenden Sie sich bitte an das Development-Büro unter Tel. XXX. 
Flyer 2016 translation:

\section{Social responsibility and sustainability}

Opera productions open up new mental spheres, making the unspeakable visible and audible, and invite the audience, every night, to experience a new cosmos with all their senses. Children have the ability to fully immerse themselves in these worlds and experience the story with the characters by partaking in their journeys on stage. Gradually they learn the language of theater, the language of pictures and movement. Those who had the opportunity to get to know these worlds as a child, will for the rest of their life benefit from the curiosity, creativity and critical abilities generated through these experiences.

Unfortunately, even today, the access to musical theater still depends on the social environment of the children. Those not lucky enough to visit the opera with their school, will be denied the fascinating world of musical theater.

Notwithstanding a collective visit of an opera performance with the family could be a highlight in family life and encourage parents and children to exchange their experiences.

Opera should be a good for all, independent of social origin and household income, it should be a possible option when spending recreational time with the family.

For this reason, we particularly want to enable children and their families from disadvantaged social backgrounds to take part in the performances of the Semperoper.

Including the children's families is an important aspect in overcoming inhibitions, relieving social injustice and establishing a lasting enthusiasm for the musical theater in the family.

Please help to facilitate the visit of an opera or ballet performance in the Semperoper for children and their families!

\section{You can win}

an opera visit in the box of the artistic director for 2 people or one of 5 DVDs of the in 2015 in the Semperoper recorded production »Der Freischütz« (Artistic director: Christian Thielemann).

\section{Your donation}

Unless you are using the attached transfer form, please transfer your donation to the following account:

Recipient: $\quad$ Sächsische Staatsoper Dresden

XXXX Sparkasse

IBAN: $\quad$ XXXX

BIC: $\quad$ XXX

Purpose: $\quad$ Spende Familienförderung + Ihre Kundennummer

\section{Donation receipt}

We are happy to send you a receipt for every donation larger than $€ 200$,- (For donations smaller than this amount the transfer receipt is usually sufficient.) In case you need the receipt to be send to a different address than in the letterhead please contact Development-Office at Tel. XXXX 
Discussion Papers of the Research Area Markets and Choice 2017

Research Unit: Market Behavior

Dorothea Kübler, Julia Schmid, Robert Stüber

SP II 2017-201

Be a man or become a nurse: Comparing gender discrimination by

employers across a wide variety of professions

Dietmar Fehr, Julia Schmid

Exclusion in the all-pay auction: An experimental investigation

SPII 2017-202

Research Unit: Economics of Change

Jannis Engel, Nora Szech

SP II 2017-301

The political economy of multilateral aid funds

Maja Adena, Jeyhun Alizade, Frauke Bohner, Julian Harke, Fabio Mesners

SP II 2017-302

Quality certifications for nonprofits, charitable giving, and donor's trust: experimental evidence

Terri Kneeland

SP II 2017-303

Mechanism design with level-k types: Theory and an application to bilateral trade

Dominik Duell, Justin Mattias Valasek

Social identity and political polarization: Evidence on the impact of identity on partisan voting trade

Maja Adena, Steffen Huck

SP II 2017-305

Narrow framing in charitable giving: Results from a two-period

field experiment 